\title{
EL PATRIMONI REIAL AL PAIS VALENCIÀ A INICIS DEL SEGLE XV
}

\author{
ENRIC GUINOT
}

\author{
SUMARI
}

I. Les rendes de la monarquia a les viles reials valencianes. - II. El patrimoni reial al País Valencià a inicis del segle XV. - Bibliografia.

L'estudi sobre el Patrimoni reial en el context de la confederació catalanoaragonesa ha gaudit fins al present d'una certa dedicació que, malgrat consistir en estudis monogràfics sobre regnats $\mathrm{i} / \mathrm{o}$ països o regions concretes, ha permès d'establir algunes de les pautes generals sobre el caràcter $o$ contingut d'aqueix patrimoni durant els segles baixmedievals $i$, fins i tot, apropar-se als nivells de la renda d'una manera quantitativa.

Aquest camp d'estudi ha rebut l'atenció dels investigadors en diversos regnats, des de l'època d'Alfons el Cast (T.N.Bisson, 1984), passant per la de Jaume I (T.N.Bisson, 1980), Alfons el Benigne (Ch.Guilleré, 1982) i Alfons Vè i Joan II (W.Küchler, 1985), fins arribar a les valoracions més generals d'un M.Sánchez (1990), T.de Montagut (1982 i 1990) i Ch.Guilleré (1990) sobre la fiscalitat i l'administració financera de la corona o les considereacions sobre els problemes del patrimoni reial de M.T.Ferrer i Mallol (1970-71); també poden afegir-se algunes edicions de fonts com ara les clàssiques de M.de Bofarull (1871) i E.González Hurtebise (1911) i la més recent de F.Vendrell (1977), així com els estudis d'algun país o regió, com ara els d'E.Sarasa (1982 i 1986), Ch.Guilleré (1984), M.Sanmartí (1982), M.L.Ledesma (1979), A.M.Aragó-R.Conde (1980) i P.Cateura (1982).

En canvi, els estudis sobre el Patrimoni Reial al País Valencià medieval no han gaudit fins el present d'una dedicació semblant a la dels altres països de la Corona catalano-aragonesa, bé siga individualment, bé siga entesa la hisenda reial central de la monarquia. Pràcticament sols podem enumerar un obra 
clàssica i que no parla específicament de l'època medieval, com la de V.Branchat (1784- 1786), alguns estudis sobre batllies locals com ara els de M.D.Cabanes Pecourt (1975), E.Guinot (1981) i P.Viciano (1992), treballs sobre els quadres de l'administració financera del regne, com ara E.Cruselles Gómez (1989), i un reduït nombre de treballs sobre el pagament a la monarquia d'algun impost o renda puntual, especialment referits a la ciutat de València i al segle XV, però sense fer cap valoració de conjưnt; a tot això podria afegir-se a tot estirar alguna obra enfocada i escrita amb un altre punt de vista, com ara la de R.I.Burns sobre els impostos que pagaven els mudèjars en temps de Jaume I i Pere el Gran, i la de M.T.Ferrer i Mallol (1988) també sobre les aljames mudèjars de la batllia d'Oriola.

$\mathrm{Al}$ cas valencià, el Patrimoni Reial té un origen molt clar: la conquesta de Jaume I. Per dret de conquesta, tot el Xarc al-Andalus pactat en el segle XII amb la corona castellana i ratificat en la seua frontera sud el 1244 al pacte d'Almirra, correspon a la corona, la qual, és clar, procedeix a un repartiment de bona part dels llocs, termes i població entre els diversos membres de la noblesa, feudal i eclesiàstica, els quals l'han ajudada més o menys directament en el procés de conquesta entre 1232 i 1245.

Amb tot, és un poc difícil parlar de què és i que comprèn el patrimoni reial al nounat regne valencià en aqueixos anys del regnat de Jaume I, perquè, el mateix procés del repartiment i repoblament del territori, va produint quotidians daltabaixos en el nombre de viles $i$ alqueries que es troben en mans de la corona o de membres de la noblesa. Amb tot, si més no, la situació comença a semblar més clara dins d'aqueixa mobilitat a la darreria del regnat de Jaume I i podem començar a identificar quines viles són de reialenc i quines de senyoria, a més de conèixer els primers recomptes fiscals conservats als registres de cancelleria; lògicament puntuals $\mathrm{i}$ irregulars, però suficients per a bastir el trellat fonamental de les rendes reials en aqueixa època.

Les fonts, però, no comencen a ser seriades quant a la hisenda reial fins el segle XIV, quan, paral.lelament a la conservació dels primers llibres de comptabilitat de la corona i dels regnes respectius a l'arxiu de la Corona d'Aragó de Barcelona, apareixen així mateix registres directament referits al País Valencià a més de liquidacions globals entre els comptes de la tresoreria del Mestre Racional -del qual són exemple els comptes publicats per E.González Hurtebise-.

A la darreria del segle XIV, el volum documental sobre la hisenda reial al País Valencià comença a augmentar significativament amb les sèries conservades a l'arxiu del Regne, de València, on apareixen els primers llibres de comptabilitat de batllies locals, com ara Xàtiva, Castelló, Morella o Alzira, sens dubte de les més importants, a més dels comptes centrals del Batlle General del Regne; aquest oficial controla la batllia de la ciutat de València, les liquidacions que li arriben de les batllies locals - de vegades molt minses perquè són molt 
elevades les despeses $\mathrm{i}$ els pagaments de donatius reials a monestirs o membres de la noblesa- $i$, finalment, una comptatilibat centralitzada sobre impostos comercials a nivell de tot el regne, com les coses vedades o la lleuda de Tortosa; els esdeveniments, multes $i$ delmes de musulmans o part d'una fiscalitat extraordinària $\mathrm{i}$ aleatòria com peticions directes del monarca a diverses viles arran de conflictes armats o necessitats urgents de la corona.

Al llarg del segle XV aquesta documentació pren un caràcter força seriat a l'arxiu particular del regne valencià en quant era generada i controlada per la seua pròpia administració $i$, simultàniament, es multipliquen els segments de documentació procedent de les batllies locals, arribant a finals de segle a conservar-se pràcticament els comptes detallats -per menut- de bona part de les batllies reials valencianes.

Així doncs, el camp de treball i recerca sembla prou definit $\mathrm{i}$ clar, i són molt amples les possibilitats que té per aconseguir-ne una reconstrucció prou satisfactòria del món del patrimoni reial i la hisenda, bàsicament entre $1350 \mathrm{i}$ 1500.

Per la nostra part, i en aquesta aproximació al tema, volem aprofitar l'existència d'una documentació especial a inicis del segle XV per aportar una primera consideració sobre aquests temes. Es tracta de la conservació a l'arxiu del Regne de València d'un gruixut manuscrit que conté un inventari parcial però aproximat dels béns i rendes del Patrimoni Reial, al País Valencià, entre 1412 i 1416 aproximadament '.

Du per títol: Libre de patrimoni del senyor Rey de la ciutat e regne de València, fet per lo bonorable micer Joban Mercader, doctor en leys, conseller del molt alt senyor Rey e Batle General del Regne de València, lo qual comenşa a regir l'offici de la Batlia General. $V$ 'die novembris anno a Nativitate Domini $M^{\circ}$ CCCC $X I I^{\circ}$. De seguit, començant per les rendes de la ciutat de València, va incorporant i relligant quaderns de diversa procedència sobre la majoria de les batllies del regne en aqueixos anys, on, amb major o menor detall, hi és inclós el llistat de rendes que té la corona en cadascú dels llocs; unes vegades són incorporats balanços o declaracions jurades dels batlles locals sobre quins elements conformen els drets i béns reials a la vila en qüestió, així com la valoració econòmica aproximada - teòrica-, que ne tenia en aqueix periode -el qual podem considerar a grans trets com a corresponent a la primera quinzena del segle XV: 1400-1415-; en d'altres casos, el manuscrit copia els llibres de comptabilitat del batlle local d'alguns dels darrers anys, tant en l'apartat de rebudes com de dates; en canvi, d'altres vegades la informació no és tan completa i sols s'hi assenyala el valor global de les rendes de la vila en qüestió així com els càrrecs

' Arxiu del Regne de València (ARV), Batllia, apèndix, n. 61. 
que ne té assignats, amb la liquidació efectiva que arriba a mans del Batlle General.

En el cas de la batllia dellà Xixona, la qual comprèn les terres del sud amb Alacant, Elx, Oriola i Guardamar, en part se'n trobava alienada en aqueixa època -Elx i Crevillent estan empenyorades a la ciutat de Barcelona- i no aporten cap comptabilitat del segle XV; el manuscrit només copia un balanç no massa clar dels comptes d'aqueixa batllia de quasi un segle abans, de 1317 a 1322. A més a més, hi ha diverses repeticions $i$, cosits en llocs diferents del manuscrit, hi apareix informació més o menys repetida d'una mateixa batllia, palesant així que només s'ha arribat a reunir documentació dispersa però que no va ser treballada en el seu moment pel Batlle General.

Resta clar, doncs, que no es tracta d'un inventari complet, acabat i posat en net de les rendes i béns de la Corona a inicis del regnat de Ferran I, sinó més bé d'un volum miscel.lani que deu pretendre posar llum en el patrimoni reial arran del nomenament del nou Batlle General Joan Mercader pel també nou monarca, i que, per les raons que siguen, no acabant de ser enllestit de bona manera, en restà aquesta compilació d'apunts i informacions locals.

Sobre el perquè d'aquest interesantíssim intent de redreç del patrimoni reial en 1412, sembla que podem dibuixar amb força claredat el seu context; justament els treballs de M.T.Ferrer i Mallol sobre la recuperació del Patrimoni reial a la darreria del segle XIV i d'E.Sarasa sobre la hisenda reial en aqueix mateix regnat del rei Ferran, ens poden situar molt nítidament el moment històric, especialment aquesta segona obra.

E.Sarasa (1986, capítol III) explica a bastament el cas del regne estricte d'Aragó. El nou monarca acabat de proclamar en 1412 sembla entrar amb força pel control dels seus regnes, afectats entre d'altres coses per l'inici d'una guerra civil amb els partidaris del comte d'Urgell; en aqueix marc, una de les línies d'assumpció del seu poder sembla ser la de la revisió dels drets i béns del seu patrimoni, afectats per una contínua alienació durant el segle XIV, però també l'angúnia per les necessitats urgents de metàl.lic per fer cara a les despeses del seu accés conflictiu a la corona i la necessitat d'imposar-se per la guerra. És així com la revisió i el control efectiu dels ingressos procedents del patrimoni reial es converteixen en un pilar fonamental de la seua política.

En el cas esmentat del regne d'Aragó, tot això va concretar-se en el nomenament d'un funcionari especial, Francesc Ferriol -que no Françés-, qui de manera paral.lela i fins i tot superior al Batlle General d'Aragó, va dur una comptabilitat completa dels ingressos reials entre 1413 i 1417 a més d'encapçalar un grapat de notaris, juristes i oficials que feren inquisicions per tot el regne confirmant, recabdant i vigilant els pagaments deguts a la corona. Simultàniament, entre 1415 i 1417 va procedir-se a la redacció d'un inventa- 
ri general o capbreu de les rendes reials amb el detall de què comprenia el patrimoni a les diverses viles $\mathrm{i}$ quins eren els drets teòrics abonats.

És aquest darrer capbreu el que pensem que té la seua correlació en el que hem citat per al cas valencià, tant pels motius que pogueren estar al darrere de la seua redacció com per les característiques informatives i històriques del text en qüestió.

El patrimoni reial al País Valencià, en ser proclamat rei Ferran d'Antequera, era format per una vintena de viles amb els seus termes respectius. Sens dubte eren les més grans, de major població i també de major volum i activitat econòmica, mercantil i manufacturera, la qual cosa no vol dir que foren les que permitien obtenir individualment $i$ una per una un major ingrés $i$ benefici per a la corona com a senyoria del lloc.

El llistat n'era format per les següents unitats o batllies, començant per la ciutat de València i després de nord a sud (veure el mapa adjunt):

1. La ciutat de València amb les seues rodalies on eren compresos un bon grapat de llocs i d'alqueries, uns de sotmesos a la ciutat i d'altres en mans senyorials, amb uns $134 \mathrm{~km}^{2}$.?

2. Morella, amb el seu terme general format pels llocs de Catí, Castellfort, Cinctorres, Forcall, La Mata, Olocau, Palanques, Portell, Vallibona, Vilafranca i Xiva de Morella, amb uns $1050 \mathrm{~km}$.quadrats.

3. Castelló de la Plana, amb uns $108 \mathrm{~km}^{2}$.

4. Vila Real, amb uns $68 \mathrm{~km}^{2}$.

5. Borriana, amb uns $47 \mathrm{~km}^{2}$.

6. Ademús, amb els termes actuals de Cases Altes, Cases Baixes i la Pobla de Sant Miquel.

7. Castellfabib, a més dels pobles de Vallanca i Torre Baixa, que sumen uns $370 \mathrm{~km}^{2}$ conjuntament amb Ademús.

8. Alpont, amb els llocs d'Aras d'Alpont, La Iessa i Titaigües, sumen uns $365 \mathrm{~km}^{2}$.

9. Morvedre, amb uns $130 \mathrm{~km}$.

10. Alzira, amb els llocs d'Algemesí, Carxaixent, Guadassuar, Benimaclí, Ternils, Cogullada, el Toro, Cabanes i Campanar, amb uns $246 \mathrm{~km}^{2}$.

11. Cullera, amb uns $53 \mathrm{~km}^{2}$.

12. Xàtiva, amb els llocs no senyorials del seu terme general: Castelló de Xàtiva, Benigànim, l'Olleria, Montaverner i l'Enova, amb uns 190 km².

2 Les extensions que anirem donant estan fetes a base de sumar tots els termes municipals amb l'extensió actual, ja que és impossible saber l'extensió exacta dels termes en època medieval. Es, per tant, un mètode aproximatiu però, amb tot, l'experiència ens ha mostrat que més enllà de rectificacions de termes en casos puntuals no hi ha hagut tants grans canvis en el pas dels segles; a més, el que ens interessa més són les proporcions, els tants per cent, perquè són els que marquen les tendències, i no tant el valor exacte de les xifres. 
13. Ontinyent, amb els actuals termes de Fontanares i Agullent, suma uns $217 \mathrm{~km}$.

14. Biar, amb els actuals llocs de Beneixama, la Canyada i Camp de Mirra, amb uns $174 \mathrm{~km}$. $\mathrm{km}^{2}$.

15. Xixona, amb els llocs d'Ibi i la Torre de les Maçanes, uns 260

16. Penàguila, amb uns $150 \mathrm{~km}$ :

17. Alacant, amb els actuals termes de Montfort, Mutxamel, Sant Joan i Aigües de Busot, uns $440 \mathrm{~km}$.

18. Oriola i Guardamar, viles que formen part de l'anomenada batllia dellà Xixona, amb un grapat de més de quinze actuals termes municipals que aleshores hi eren simples alqueries incloses en els termes generals respectius, uns $885 \mathrm{~km}^{2}$.

19. L'antic patrimoni: Llíria (19A) Sogorb (19B), Xèrica amb els llocs del seu terme: Viver, Caudiel, Toro, Pina, Barraques i Novalitxes (19C), i les aljames de la Vall d'Uixò (19D), Serra d'Eslida (19E), Castro (19F), Vall d'Almonesir (19G), Paterna (19H) i Benaguasil, aquesta amb el lloc de cristians de la Pobla de Vallbona (19I).

El manuscrit esmentat inclou en diversos apartats allò que anomena "les viles e lochs de don Frederich e altres viles e locs del senyor Rey». Es tracta de la senyoria integrant de l'antic comtat de Xèrica del segle XIV, que passà a mans de l'infant Martí arran del seu matrimoni amb Maria de Luna en 1372. Quan aquest infant esdevingué monarca, aquestes viles quedaren incloses dins el patrimoni familiar de la corona, enteses com una senyoria particular pròpia, raó per la qual no tenen una batllia pròpia ni són "de reialenc» -per exemple no tenen representació en Corts-, però les seues rendes apareixen inventariades com a tals béns del patrimoni reial $\mathrm{i}$ formant part dels seus ingressos ordinaris. Reuneixen una extensió d'uns $932 \mathrm{~km}^{2}$.

En resum, 24 ciutats $i$ viles, $i$ un poc més de 50 llocs i alqueries, la gran majoria de cristians i sols una desena d'aljames musulmanes: Benaguasil, Paterna, la Vall d'Uixò, Serra d'Eslida, Castro i la Vall d'Almonesir com aljames rurals, i les moreries urbanes de València, Alzira, Xàtiva i Sogorb.

Entre tots els termes del reialenc sumarien una extensió aproximada d'uns $4.900 \mathrm{~km}^{2}$, tenint en compte les 18 batllies com a tals; a aquests podria afegir-se d'alguna manera el cas esmentat de les viles de l'Antic Patrimoni, amb la qual cosa s'arribaria a uns $5.800 \mathrm{~km}^{2}$, malgrat que no formen part estricte del «reialenc», tal com ho hem explicat.

En aquest segle XV el País Valencià no incorporava una sèrie de comarques que formaven part de Castella, com les de Requena-Utiel i el marquesat de Villena, al sud; això significa que la seua extensió total era d'uns $21.660 \mathrm{~km}^{2}$ i 
la corresponent al reialenc estricte un $23 \%$, quasi una quarta part del regne :

\section{LES RENDES DE LA MONARQUIA A LES VILES REIALS VALENCIANES}

Un treball que no havia estat plantejat fins ara és el de reconstruir els components de la renda feudal a cadascuna de les batllies reials del País Valencià i analitzar el seu caràcter, a més d'intentar avaluar les quantitats dels ingressos ordinaris a través del patrimoni reial per a la corona en aquest periode del regnat de Ferran I.

Una part de la informació procedeix de l'esmentat capbreu de 1412-1414, però ha calgut completar en diversos casos la informació a través dels llibres de comptabilitat de les batllies locals quan ha estat possible. Els quadres solen dur quantitats molt exactes, fruit del valor anual corresponent; és clar que això fluctuaria d'any en any i per això ens basem per a l'estudi i evaluació en les proporcions $i$ tants per cent.

Els resultats són els següents:

\section{1.- Ciutat de València:}

1. Taula del pes reial

66.810 sous

2. Lleuda de Tortosa

$31.373 \mathrm{~s}$.

3. Dret dels italian

$18.949 \mathrm{~s}$.

4. Coses vedades

$5.119 \mathrm{~s}$.

5. Manifest jueus Berberia

$158 \mathrm{~s}$.

6. Terç de delme . . . . . . . . . . . . . . . $20.196 \mathrm{s.}$

7. Almodí ......................... $5.423 \mathrm{s.}$

8. Alfondec .................... $2.440 \mathrm{~s}$.

9. Dret del faixcar . . . . . . . . . . . . . . . $1.047 \mathrm{s.}$

10. Censals menuts . . . . . . . . . . . . . . . . . $4.055 \mathrm{s.}$

11. Lluissmes . . . . . . . . . . . . . . . . . . $2.325 \mathrm{s.}$

12. Batllia de la moreria ............... $1.070 \mathrm{~s}$.

' En un altre treball nostre (Guinot, 1992a) datat a la darreria del segle XV, hem calculat una distribució geogràfica del patrimoni reial força semblant, amb poques diferències de conformació entre les grans viles que el formaven $i$ una extensió lleugerament superior, d'un $27 \%$ del regne, fruit de la incorporació d'alguna vila procedent justament del que hem anomenat «Antic Patrimoni», cas de Llíria. Si més no, les diferències semblen molt reduïdes $\mathrm{i}$ deuen tenir un caràcter d'elevada estabilitat en la seua composició per a tot aqueix segle $\mathrm{XV}$. 
13. Delmaments $\mathrm{i}$ vendes de moros i acaptar ..... $17.352 \mathrm{~s}$.

14. Composicions i multes .............. $66.567 \mathrm{~s}$.

15. Gabella de la sal ............... $25.810 \mathrm{~s}$

16. Quint del peix de l'Albufera ......... $25.810 \mathrm{~s}$

17. Banys de la moreria ............... -

18. Cenes viles Regne .................. $2.400 \mathrm{~s}$.

19. Morabatí viles Regne ................ $6.624 \mathrm{~s}$.

(Quadre 1).

Les rendes de la batllia de la ciutat de València tenen un caràcter especial en quant sumen les obtingudes tant a la mateixa ciutat com les recaptades per alguns apartats en tot el Regne. Entre les primeres es trobarien el terç de delme i tota mena de monopolis -almodí, alfondec, censals menuts de forns, molins, cases, obradors, etc., els lluïsmes de la venda d'aqueixos immobles, el dret del faixcar, la gabella de la sal i el quint del peix de l'Albufera-, a més de les rendes de la moreria; el seu conjunt arribaria a sumar quasi un $23 \%$ de les rendes d'aquesta batllia, d'on les $3 / 4$ parts restants són ingressos procedents més o menys directament de tot el Regne -n'és el cas de les rendes comercials, difícils de destriar les locals de les forànies-, centralitzats tots a la ciutat.

El terç de delme era cobrat pel Rei a quasi totes les viles reials valencianes, $i$ sol aparèixer gravant els diversos cereals, la collita del vi i les hortalisses, a més del ramat que naix anualment -nomenat a la documentació carnatge-; quant al concepte "censals menuts», és terme comú als documents de la majoria de les viles valencianes i fa referència als censos emfitèutics -quasi sempre en metà1.lic- que n'eren pagats pels monopolis establerts -forns, molins, carnisseries, pescateria, almàsseres, etc.-, però també per cases, terres, obradors artesanals 0 escrivanies públiques.

El detall dels censals menuts de la ciutat de València no és possible coneixer-lo en la seua major part car varen ser alienats tots els existents per Pere el Cerimoniòs vers 1340 en favor dels capellans del Palau Reial de València,

4 Aquest quadre ha estat tret a partir de les rendes ordinàries de l'any 1415 dels comptes del Batlle General del Regne en aqueix any. (ARV, MR, n.36). Hem revisat també els anys anteriors, 1412, 1413 i 1414, en els quals lògicament les xifres concretes fluctuen i són, en general, un poc més baixes que les detallades ací. El manuscrit de les rendes generals (A.R.V.,Batllia, apèndix n.61, f.1-16) enumera sols una part d'aquestes rendes, en concret la taula del pes reial, almodí, batllia de la moreria, terç de delme i censals menuts, però faltant bona part de les rendes comercials, la qual cosa no permet fer un balanç global solament amb aqueixa font sobre la ciutat. 
amb una suma de 2.893 sous; posteriorment varen continuar els establiments de diversos monopolis -obradors, molins, forns, etc.- fins un valor en aquests anys de $1.162 \mathrm{~s}$. més ( 9 obradors fan $204 \mathrm{~s}$, 7 forns fan $61 \mathrm{~s}$, 3 molins fan 17 s., 1 carnisseria fa 7 s., 5 heretats fan 12 s., i les 3 escrivanies de les corts del Batlle, Justícia i Governador foren establertes per 121 s.en total); allò més significatiu és el poc valor individual de cadascuna d'aquestes rendes, molt inferiors al seu valor en cas de ser arrendades.

La majoria de les rendes centralitzades a València, però, procedeixen del comerç i la seua variada fiscalitat: taula del pes reial, lleuda de Tortosa, dret dels italians, coses vedades i el manifest pagat pels jueus que duen productes de Barbaria; totes aquestes venen a sumar vora un $45 \%$ dels ingressos de València, malgrat que no tota la fiscalitat comercial es troba directament en mans reials -seria el cas de les Generalitats-. El segon gran bloc són les composicions i multes, així com els delmes i vendes de moros; aquests ingressos de l'activitat jurisdiccional apareixen freqüentment a la documentació sota el nom d' «esdeveniments», terme que hem mantingut en els quadres d'altres viles en fer referència a aqueixes multes $\mathrm{i}$ calònies; la monarquia tenia centralitzada a València una part del rendiment econòmic del sistema judicial, en mans del Batlle General, el qual recaptava tant multes sobre musulmans com sobre certs casos de cristians, normalment per delictes de mer imperi; en raó d'això una part d'aquestes són de valor elevat, fins i tot de milers de sous; així mateix, el Batlle General cobrava els delmes dels moros que volien abandonar el Regne, venia esclaus sarraïns $i$ cobrava per atorgar el dret d'acaptar-demanar almoina per a la redempció de la seua esclavitud-; crida l'atenció que en aquest cas específic aquestes rendes són prou altes en conjunt, molt més del que pot trobar-se en les viles normals, $\mathrm{i}$ sumen quasi un terç de les rendes de la batllia de València.

Així doncs, les rendes de la ciutat de València presenten netes peculiaritats: la primera, que pràcticament quasi no hi ha rendes fixes -els censals menuts d'obradors, forns, molins, etc.- perquè tota la resta és arrendada majoritàriament. A més, una part important dels ingressos (un terç) és aleatòria, ja que procedeix de les multes, composicions i avinences per processos judicials, i també dels delmes i drets d'acaptar dels musulmans de tot el regne; és raonable considerar que poguera fluctuar molt, però el buidament dels ingressos de 1413 i 1414 mostra que es tracta de xifres molt elevades generalment. Així mateix, el que les rendes comercials representen el $45 \%$ dels ingressos reials a la ciutat no és normal per a la resta del regne i està en funció de la inexistència d'impostos directes com ara la peita i la cena, i, és clar, del caràcter de gran nucli comercial mediterrani i del país que té la ciutat.

2.- Morella:

1. Peita ...................... 16.000 sous 


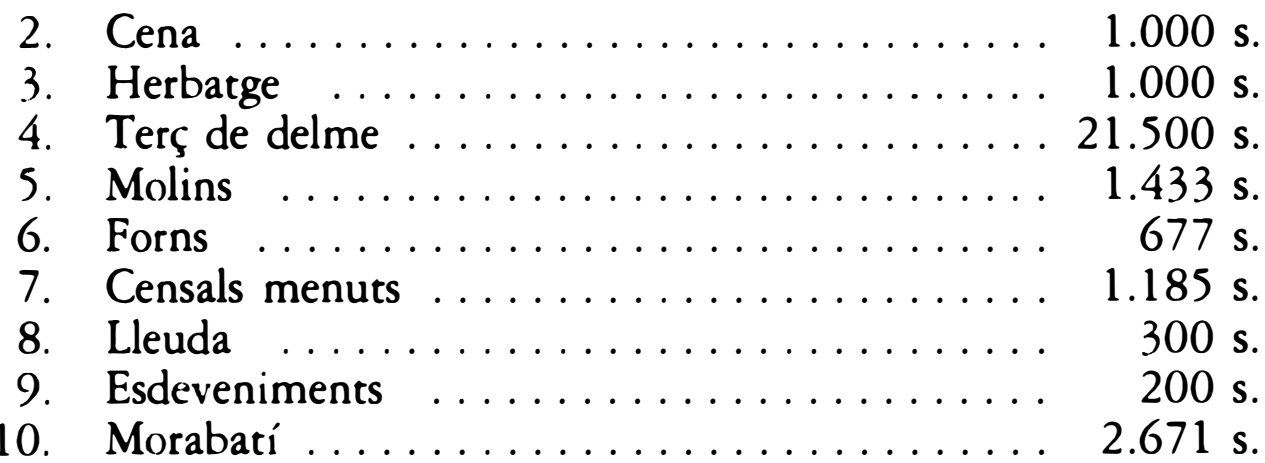

45.966 s./any'

(Quadre 2).

La renda ordinària de la monarquia a Morella té dos components fixes que són: una molt elevada peita, la més alta del regne per cert, una cena proporcional, $i$ un herbatge establert emfitèuticament al consell municipal en 1.000 s.anuals, la qual cosa permet que Morella i les aldees disposen del seu propi tribunal i fiscalitat ramadera per a forasters: el lligalló; tot sumat, arriba als 18.000 s., això és, un 39,2\% aproximat de les rendes totals.

El 60' $8 \%$ restant és fluctuant en funció dels arrendaments o nivells anuals i se'n troba dominat per un molt important terç de delme -el $46^{\prime} 7 \%$ de les rendes del terme-, acompanyat d'un grapat de monopolis i quantitats molt testimonials procedents del comerç -lleuda- i multes derivades del funcionament de l'aparell judicial -esdeveniments-.

El terç de delme procedeix de la producció tradicional a la comarca, quasi en la seua meitat del forment, i també de la "mestura» o "centeno", de l'ordi, de «l'avena» i del vi; també hi ha una part del carnatge i, en menor mesura, del safrà.

' Com a la resta de pobles, en el llistat hem fet dos blocs, posant-hi en el primer les rendes fixes anuals $i$ en el segon, separades per una línia en blanc, les rendes variables en funció de ser arrendades periòdicament -anual, bianual, etc.- o per ser aleatòries -multes, impostos del comerç, morabatí-.

Les dades de Morella han estat tretes del llibre de rendes del Batlle General del regne del 1414, (ARV, Batllia, apèndix n.61, f.39 $\mathrm{r}^{\circ}-55 \mathrm{r}^{\circ}$ ), , i completades amb les liquidacions del batlle local en la seua administració dels anys 1413 a 1418 (ARV, Mestre Racional, no 3724). El primer manuscrit inclou un detall de tots els censals menuts del terme general de Morella, relacionant-los-hi un per un pels 14 pobles que inclou: la mateixa Morella i Vallibona, Palanques, Xiva, Cinctorres, Forcall, Vilafranca, Castellfort, Salvassòria, Herbés Sobirans, Olocau, Catí, La Mata i Portell. Els comptes del batlle local presenten un arrendament general anual que inclou el terç de delme de tots els llocs així com els censals menuts i la lleuda; però en 1416 no foren arrendats i disposem així per a un any del detall exacte de les rendes, si més no interessant pels valors proporcionals que ens aporta. 
Quant els censals menuts, aquests estan formats pels diversos censos anuals -en metàl.lic l'aclaparadora majoria- $\mathrm{i}$ un menut grup de censos en espècie procedents dels molins; el detall n'és el següent:

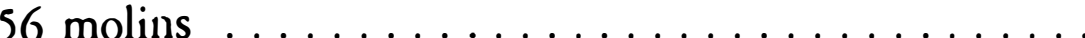

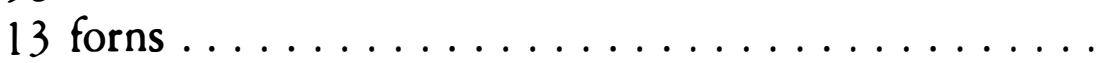

1.433 s.

677 s.

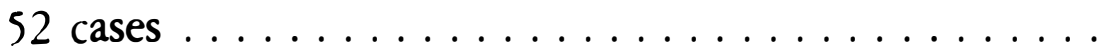

111 parcel.les de terra $\ldots \ldots \ldots \ldots \ldots \ldots \ldots \ldots$

$446 / 9$ s./d.

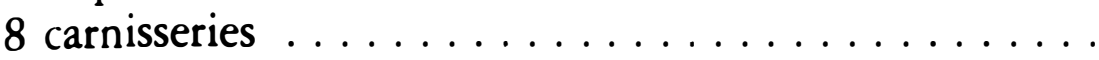

$103 / 10 \mathrm{~s} . / \mathrm{d}$.

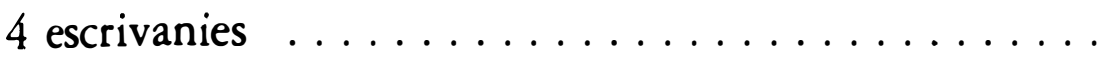

2 pagaments de rectors de Morella ...........

Aquesta quantitat no és fixa perquè, com déiem, els censals de molins són en part en espècie -38 cafissos de diversos blats- $i$ oscil.len lleugerament els preus de venda d'uns anys a uns altres. Tots els monopolis apareixen repartits pels diversos pobles, però la major part de l'ingrés procedeix dels situats al terme estricte de Morella -sobre un $60 \%$-. Per exemple, totes les cases que fan cens es troben en aqueixa vila, i allí també hi ha aqueix pagament de $250 \mathrm{~s}$. de cadascuna de les dues parròquies de la vila, del qual no hem pogut aclarir l'origen o significat.

Sobre la lleuda, l'inventari del Batlle General en fixa un ingrés de 300 sous, però el detall dels comptes del batlle local aporta 617 s. en 1416 i 622 en 1417. Finalment resta l'apartat que hem anomenat «esdeveniments»; és aquest un terme emprat pels oficials reials en la documentació consultada juntament amb el d'uemoluments», i correspon a la part que pertoca al monarca de les multes imposades pels diversos oficials locals al llarg del seu ofici anual, una vegada descomptades despeses i salaris. Solen ser quantitats molt baixes i, a més, molt irregulars en el seu volum, la qual cosa fa que siga difícil de quantificar de forma més o menys estàndard per poder treure valors proporcionals. En el cas de Morella procedeixen dels tribunals o corts del Justícia criminal, del Justícia dels 300 sous i del Justícia del lligalló ramader; en el quadre 2 hem posat aqueixos 200 sous com mitjana aproximada dels anys 1413 a 1417; amb tot, cal assenyalar que el 80 o $90 \%$ procedeix de la cort del lligalló.

La documentació local no inclou en aquest cas l'apartat del morabatí, segurament perquè en aqueixos anys el rebia la regina. La xifra l'hem trobada en els registres del morabatí de l'any 1415 , i l'hem inclosa amb el sistema proporcional d'un sou per foc $i$ any; aquest sistema és l'emprat en la comptabilitat d'altres batllies valencianes, tal com ho veurem, $i$ hem considerat que 
convenia afegir-lo en aquest cas i algun altre de cara a unificar criteris i nivells d'exacció, més enllà de qui siga el seu beneficiari darrer.

El resum del cas de Morella ens mostra, doncs, una estructura de la renda reial ordinària molt decantada entre una fiscalitat directa fixa (peita, cena $\mathrm{i}$ cens de l'herbatge) i les rendes de la terra procedents del terç de delme, mentre que els monopolis i ingressos restants són molt més reduîts; aquest model de renda és el que trobarem a grans trets com a més comú a les viles reials valencianes.

3.- Castelló de la Plana:

1.- Peita

2.- Cena

3.- Terç de delme

4.- Molins

5.- Censals menuts

6.- Lluïsmes

7.- Coses vedades

8.- Esdeveniments

9.- Morabatí
5.000 sous

$1.000 \mathrm{~s}$.

$8.500 \mathrm{~s}$.

$700 \mathrm{~s}$.

$500 \mathrm{~s}$.

$200 \mathrm{~s}$.

$800 \mathrm{~s}$.

$250 \mathrm{~s}$.

$800 \mathrm{~s}$.

17.750 s./any ${ }^{\circ}$.

(Quadre 3).

La renda reial ordinària de Castelló té $6.000 \mathrm{~s}$. fixos anuals de la peita i la cena (sobre un terç dels ingressos aproximats), mentre que la resta és fluctuant. Les quantitats que hem indicat en el quadre de la resta d'apartats són mitjanes aproximades ja que disposàvem del seu detall per a tots els anys del període 1412-1417.

Els censals menuts corresponen als censos d'11 molins (uns 80 s. fixos en metàl.lic i la resta en espècie, per la qual cosa fluctuen d'any en any en funció del preu del forment i ordi, però que vindria a ser un ingrés d'uns $620 \mathrm{~s}$. més); els censos de les cases sumen uns $200 \mathrm{~s}$. més; els dels forns uns 80, el mateix aproximadament que els de les 15 taules de carnisseria; les parcel.les de terra (una vintena) representen un ingrés fix d'altres 70 sous més o menys, i cal afegir finalment $3 \mathrm{~s}$. d'una almàssera, 27 de les dues escrivanies de les corts del

" La font en el cas de Castelló també és el llibre del Batlle General (A.R.V., Batllia, apèndix núm. 61, ff. 27 r.-35 v. i 455 r.- 467 r.), així com els comptes del batlle local de Castelló de 1405- 1420 (ARV, MR, núms. 2448 i 2449). Cal subratllar el molt brillant treball de Pau Viciano sobre aquesta batllia, (P.Viciano, 1992). 
Justícia i del batlle, $18 \mathrm{~s}$. de cens dels banys, $9 \mathrm{~s}$. del forn de la cera i $11 \mathrm{~s}$. de censos de 3 obradors. En conjunt, una clara primacia de les rendes dels molins, gràcies a ser en bona part en espècie; crida l'atenció que a una vila com Castelló quasi no hi haja obradors a cens, fet que és freqüent a la resta de grans viles reials. Aquest apartat es veu completat pels lluïsmes, procedents de les vendes dins l'any fiscal d'aqueixos monopolis cedits en emfiteusi.

Els esdeveniments corresponen, tal com n'hem explicat abans, a la part reial de les multes imposades pel Justícia local, mentre que l'apartat «coses vedades" correspon a aqueix impost de tipus comercial però que generalment apareix incorporat en els comptes del Batlle General del regne i no en els dels batlle local. El morabatí també ha estat afegit en base als comptes de la seua recaptació en 1415, per les mateixes raons i mecanismes explicats anteriorment.

El resum també mostra el fort caràcter dual de la renda reial en aquesta vila: el terç de delme equival a vora un $50 \%$ dels ingressos i la renda fixa directa (peita i cena) un $33 \%$ més.

4.- Vila Real:

1.- Peita . . . . . . . . . . . . . . . . . . . 1.000 sous

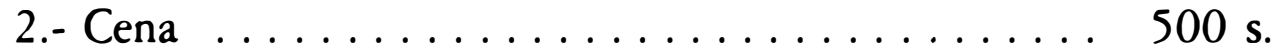

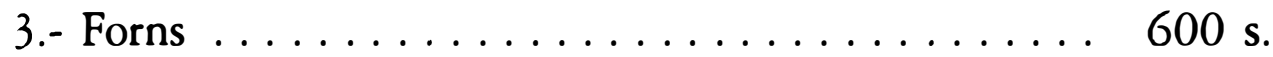

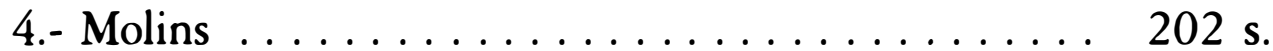

5.- Censals menuts ................ 222 s.

6.- Terç de delme ................... $2.000 \mathrm{s.}$

7.- Morabatí .................... 400 s.

8.- Esdeveniments . . . . . . . . . . . . . . 200 s.

\section{$5.124 \mathrm{~s} . /$ any \\ (Quadre 4) '.}

En el cas de Vila Real podem fixar-nos en el fet que les rendes són prou més baixes que en els casos anteriors, tant les fixes com les fluctuants, amb el terç de delme al davant. Les proporcions són ara també diferents ja que les fixes anuals representen vora el $50 \%$ de les anuals (peita, cena i censals menuts). La renda bàsica és el terç de delme -quasi un $40 \%$-, mentre que uns altres dos $20 \%$ venen de la peita i dels censos emfitèutics respectivament, per la qual cosa els ingressos de la hisenda reial també poden considerar-se prou polaritzats.

' Les fonts sobre les rendes de Vila Real corresponen a l'esmentat llibre del 1414 (ARV, Batllia, apèndix núm. 61, ff. 24 r.-26 v., i 220 r.). 
Els censals menuts munten una quantitat fixa anual ja que tots corresponen a béns i monopolis establerts en diners; els més importants com ara 1 molí i els 3 forns, ho són en favor de la mateixa vila; cal adonar-se que tant a Vila Real com a la resta de pobles no devien ser aquests els únics molins, forns, etc., existents, sinó solament els establerts en emfiteusi; perfectament podien haverne més en propietat alodial i la seua existència caldria ratificar-la en altres tipus de fonts.

Hem pogut destriar-los individualment i presenten la següent relació:

7 molins ...................... 202 s.

3 forns ...................... 600 s.

9 obradors ...................... 99 s.

1 escrivania de la Cort $\ldots \ldots \ldots \ldots \ldots \ldots \ldots$ s.

11 parcel.les de terra ............... $38 \mathrm{~s}$.

1 hostal ...................... 30 s.

2 cases ....................... 10 s.

$1.024 \mathrm{~s}$.

Quant a altres rendes, tan sols apareix en la documentació del Batlle el morabatí -el qual ara sí que és inclós directament per la documentació, malgrat que amb una xifra inferior a la reflectada en la col.lecta de l'any 1415; així mateix, en una segona relació de les rendes de Vila Real, el Batlle General va incloure l'apartat d'esdeveniments amb un valor anual reduït $-200 \mathrm{~s}$. o el $4 \%-$.

Dins les pautes comunes de renda que anem trobant a poc a poc, Vila Real presenta un model senzill, amb el predomini del delme i de la peita i uns censals menuts un poc més alts de la mitjana; crida també l'atenció que el delme no siga més alt en valor absolut, $i$ que les quantitats que apareixen en la documentació estiguen clarament arrodonides, palesant així el seu caràcter de valors mitjans.

\section{5.- Borriana:}

1.- Peita ........................2.000 sous

2.- Cena ...................... $900 \mathrm{~s}$.

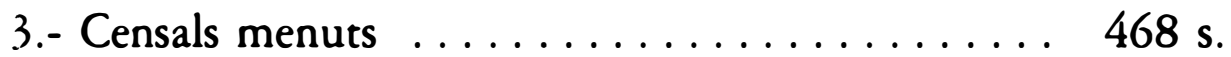

4.- Peita dels jueus .................. 200 s.

5.- Terç de delme ...................... $1.400 \mathrm{~s}$.

6.- Gabella de la sal .........................

7.- Morabatí ..................... $400 \mathrm{~s}$. 
8.- Esdeveniments

$250 \mathrm{~s}$.

$6.968 \mathrm{~s} . /$ any

(Quadre 5)".

Les rendes de Borriana mostren una forta dualitat entre rendes fixes $\mathrm{i}$ variables en funció dels arrendaments anuals. En aquest cas les primeres -peita, cena i censals menuts-sumen sobre la meitat del total; convé subratllar l'aparició d'una peita dels jueus -de poc valor-, la continuiitat de la qual degué estar en funció de les vicissituds d'aquesta comunitat. Així mateix, dins el concepte de cena hi ha dos apartats: 700 sous corresponen a la cena ordinària de la vila de Borriana, mentre que els altres 200 s. són pagats com a tal cena diferenciada per l'Orde de Montesa sobre els vassalls que té dins el terme de la vila.

Els censals menuts representen una quantitat no massa elevada però constant en quant tots són censos fixos en diners; una altra cosa és que puguen fluctuar en períodes d'uns quants anys en raó del fet què es produixquen abandonaments de cases, obradors, etc. El seu detall també hem aconseguit trobar-lo i és el següent:

28 obradors . . . . . . . . . . . . . . . 394 s.

1 molí ....................... $50 \mathrm{~s}$

1 escrivania de la Cort ................ 9 s.

2 horts .................... 9 s.

la casa de la presó ............... $6 \mathrm{~s}$.

$468 \mathrm{~s}$

Crida l'atenció d'immediat la nul.la presència dels tradicionals i més rendibles monopolis -forns i molins (llevat d'un) i fins i tot carnisseries-, mentre que la presència d'obradors és molt elevada, dominant de totes totes. Probablement les raons caldria buscar-les en les condicions del repoblament al segle XIII, quan la monarquia degué fer una alienació general d'aqueix tipus de béns per recompensar persones concretes; amb el temps, a d'altres viles el creixement demogràfic va permetre als reis establir nous monopolis a canvi de censos però, potser, en el cas de Borriana, no va produir-se un creixement semblant.

${ }^{8}$ Les fonts sobre les rendes de Borriana corresponen al manuscrit de la Batllia (apèndix núm. 61, fols. 19 r.-22 v. i ff. 448 r.- 451 r.), i també dels comptes del batlle local en 1421-1422, primer any conservat (ARV, MR, núm. 1951). 
Entre les rendes variables $\mathrm{i}$ en part arrendades anualment, apareix un terç de delme prou reduït (sols munta el $20 \%$ d'aquestes), i un apartat no gaire freqüent: la gabella de la sal, la qual abastava les comarques centre-nord del país, entre Castelló i Morvedre aproximadament. És un ingrés significatiu, car ve a representar vora un altre $20 \%$, i per això altera en bona part les proporcions de rendes més freqüents que podem trobar en el conjunt del regne.

Finalment apareixen dos apartats més: de nou el morabatí, amb les mateixes característiques i raons que abans hem exposat per al cas de Vila Real, i els «esdeveniments", que, pel que hem pogut comprovar en els comptes del batlle local en 1422, inclou tant els ingressos de les multes del Jústícia local com dels lluïsmes dels béns emfitèutics, bàsicament els obradors esmentats.

El cas de Borriana, per tant, presenta lleus variants respecte el model més comú de rendes reials, en tant en quant inclou ingressos especials com ara la gabella de la sal -de valor important-, i el fet que la fiscalitat directa -peita i cena-, és superior al delme.

\section{6.- Ademús:}

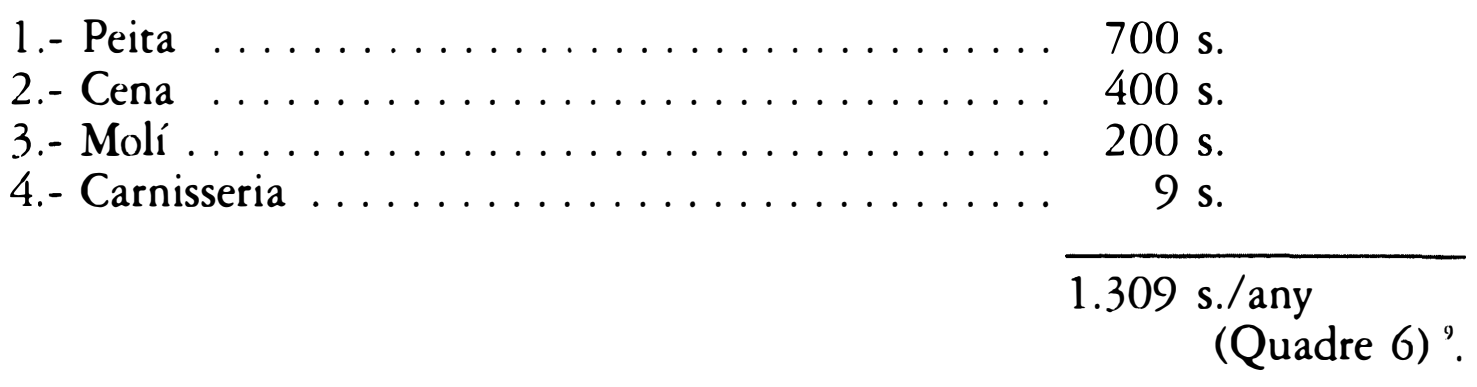

Sobre les rendes d'Ademús, crida d'immediat l'atenció un fet fonamental: que no hi ha ingrés procedent de la part del delme, la qual cosa fa que el seu valor total siga francament reduït. Desconeixem les raons d'aquest fet, el qual sols es dóna en altres dues viles reials valencianes: justament la veïna Castellfabib i la vila d'Oriola; això ens fa sospitar la hipòtesi de si deu tenir alguna cosa a veure amb els origens cristians d'ambdós llocs, inicialment adscrits al regne d'Aragó $\mathrm{i}$ sols unes dècades després de la conquesta de València incorporats al nou regne en el cas d'Ademús i Castellfabib, i procedent de la conquesta castellana -amb el seu sistema fiscal tal com veurem més avant- en el d'Oriola.

"La font ha estat elllibre del Batlle General (ARV, Batllia, apèndix núm. 61, f. 131 r. i f. 223 r.-v.). No hi ha informació sobre el comptes del batlle local d'aquest lloc, comprés dins la batllia de Castellfabib, fins el 1469. 
El resultat, però, d'aquesta peculiaritat, a la qual cal afegir uns monopolis molt reduïts i centrats sols en un molí i una carnisseria -ambdues coses a cens fix-, és que la renda reial d'Ademús és constant en el temps i en un $84 \%$ corresponent a la fiscalitat directa sobre la comunitat, materialitzada per la peita i la cena.

\section{7.- Castellfabib:}

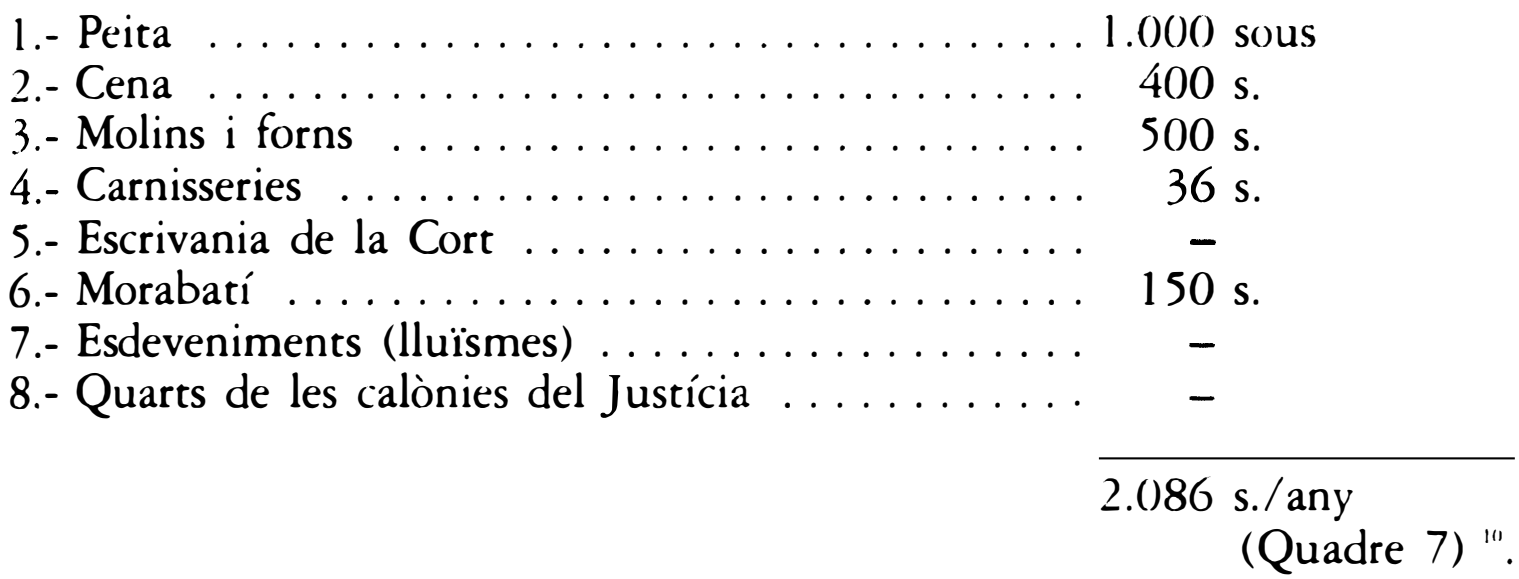

Les rendes de Castellfabib presenten les mateixes peculiaritats que les de la vila anterior d'Ademús, amb l'absència del terç de delme; això du al fet que la peita i cena -rendes fixes anuals- munten a més del $70 \%$ del total. Es diferenciaria del cas anterior en una renda prou més alta dels molins i forns, els quals, si més no, són una renda fixa anual pagada per la vila, la qual té establerts ambdós apartats.

Tal com pot veure's al quadre superior, apareixen apartats en blanc dedicats al cens de l'escrivania de la Cort del Justícia, al morabatí, als esdeveniments (en aquest cas sols el lluïsme) i als "quarts de les calònies del Justícia local»; això és perquè així és tal com apareixen enumerats i identificats per separat en el llibre del Batlle General en base a l'informe del batle local. Pensem que és clar que consideren aqueixos apartats com a font d'ingressos corrent i podria explicar-se el fet que no ompliren les quantitats corresponents, en què el seu volum fóra molt reduiit, cosa que hem vist per a lluïsmes i multes, i en un altre cas al fet que el caràcter especial del morabatí duguera el batlle a la decisió de no especificar quantitat. En tot cas, la xifra d'aquest darrer l'hem

11 La font sobre les rendes d'aquesta vila és el llibre del Batlle General de 1414 (ARV, Batllia, apèndix núm. 61, ff. 243 r.-246 v.), ja que, tal com n'hem dit abans, no hi ha comptabilitat del batlle local fins el 1469. 
trobada en els quaderns de la col.lecta de 1415 , i per això hem inclós aqueixos 150 sous/any.

8.- Alpont:

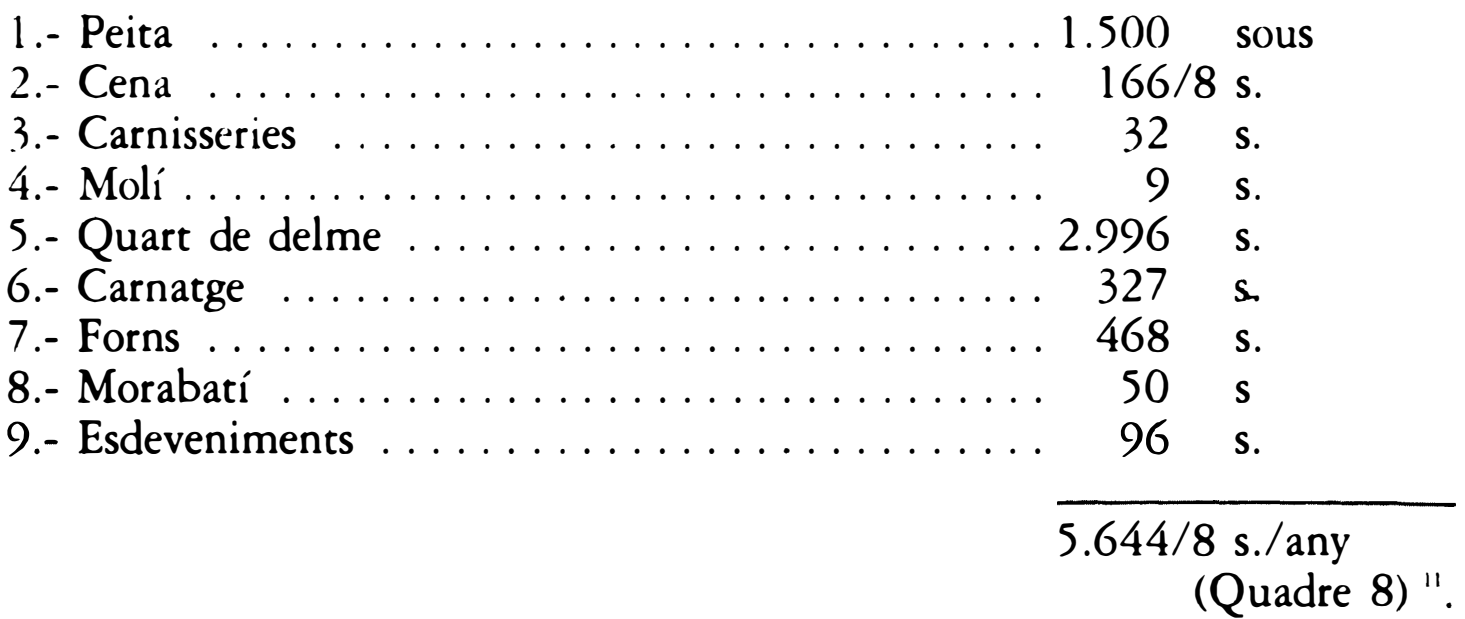

Alpont mostra una configuració de la renda reial més a prop del model comú que anem trobant per enlloc del país. Una renda fixa - peita i cena, a més de dos monopolis establerts a cens emfitèutic fix anual en diners -el molí $i$ les carnisseries del mateix Alpont, La Iessa i Aras-, que tots sumats volten el $30 \%$ de les rendes de la vila.

El $70 \%$ restant procedeix de la partició del delme, el qual, en aquesta vila, i a diferència d'allò corrent al regne, és sols d'una quarta part del delme total; també procedeix del quart de delme dels animals nascuts durant l'any -carnatge-, de l'arrendament dels forns de la vila, i de dos ingressos de caràcter més reduït: el morabatí $\mathrm{i}$ els esdeveniments.

L'ingrés dels forns és mixt, amb una mínima quantitat del cens fix en diners dels de La Iessa i Ares -9 s. cadascú-, mentre el seu valor fort són els 450 s. aproximats que hom trauen anualment en ser-ne arrendats els de la vila d'Alpont.

Resten el morabatí, el qual també ací és comptabilitzat de forma anual -tal com apareix en una part de les batllies valencianes-, mentre que sota el títol "esdeveniments» deurem trobar la part de les multes tocant al rei d'aquelles imposades $\mathrm{i}$ cobrades pels oficials locals ja que la quasi total absència de béns emfitèutics fa improbable que aqueixa siga també una font corrent.

"Les rendes d'Alpont procedeixen del llibre del Batlle General (ff. 146 r.- 160 r., i ff. 230 r.- 236 v.), el qual inclou els comptes del batle local dels anys 1410 al 1414. 
En conjunt, les rendes d'Alpont tenen la tradicional polaritat que estem trobant per tot el país, i procedeixen majoritàriament del delme -un $58 \%-$, seguit de la fiscalitat reial directa -peita, cena i, en certa manera, morabatí, els quals no arriben a un $33 \%-$, i els monopolis omplint el $9 \%$ restant; les rendes procedents de la justícia, tal com pot veure's al quadre adjunt, són mínimes.

9.- Morvedre:

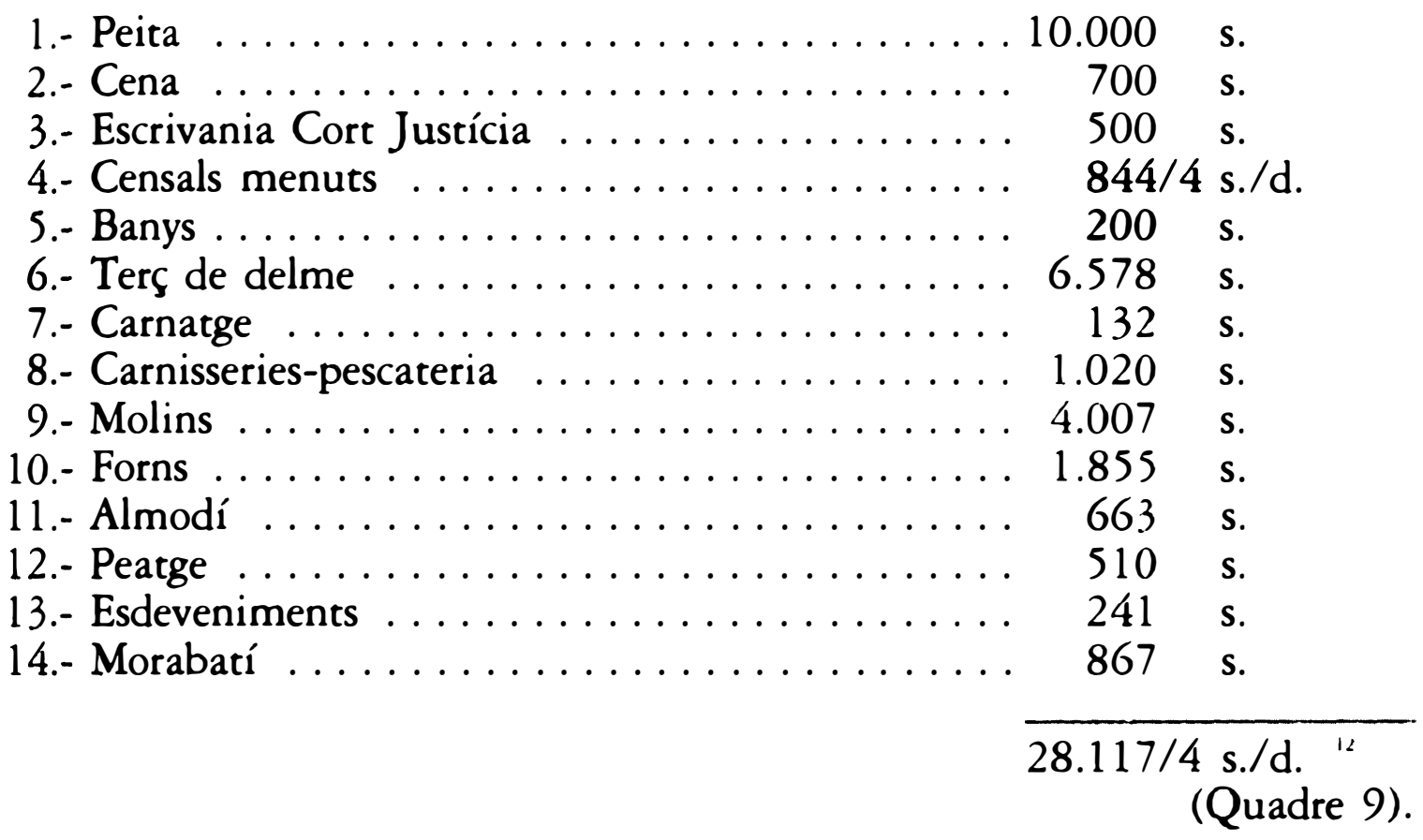

Morvedre és una de les grans viles reials de regne i sens dubte açò té relació amb el fet que presente una varietat de rendes superior a la d'altres viles més menudes, així com un valor total també més considerable.

Les rendes fixes corresponen a les tradicionals peita i cena, l'escrivania de la Cort $\mathrm{i}$ un grapat considerable de censos en diners procedents de cases, terres $\mathrm{i}$ obradors a més dels banys, tots els quals vénen a ser el $45 \%$ de les rendes totals. La resta, el $55 \%$, pot fluctuar més o menys d'any en any en funció del valor aconseguit en els arrendaments corresponents, i és dominat clarament per un

${ }_{12}$ La font sobre les rendes de Morvedre procedeix bàsicament del llibre del Batlle General (ff. 176 r.-190 r., i també ff. 214 r.-217 v.), on consten amb molt de detall els valors dels arrendaments de tots i cadascun dels impostos recaptats pel batlle local en els anys 1406 a 1409. 
terç de delme que ve a representar un altre quart de les rendes d'aquesta vila.

Podem fixar-nos en la forta peita, superior en valor al terç de delme, la qual cosa no és molt freqüent, i el mateix passa amb l'abundància proporcional de censos de cases i obradors; amb tot, el seu valor en diners és baix en comparació amb la renda total de la vila; així mateix, també és peculiar el fort cens fix anual de l'escrivania i el dels banys.

El terç de delme és el comú a la resta de viles valencianes, gravant els cereals (pa), vi i oli, a més del lli, cànem, garrofes, figues, hortalisses i el carnatge del ramat; en aquest cas el seu valor és inferior a la mitjana de les viles reials.

Les rendes variables tenen a Morvedre una important peculiaritat: per primera vegada en tot el que hem vist fins ara, els principals monopolis són arrendats anualment $i$ això fa que els seus ingressos siguen molt elevats; entre aquests destaquen els molins -aqueixos a soles valen el $14 \%$ de les rendes de Morvedre-, seguits dels forns i de les carnisseries; aquests tres monopolis junts sumen el mateix valor anual que el terç de delme, $\mathrm{i}$ un poc més encara si hi afegim els banys, l'almodí $i$ els censals menuts; d'aquests darrers no hem pogut esbrinar-ne la seua composició detallada.

Resten alguns ingressos menors i de caire diferent: una renda directament comercial com és el peatge -i que no val ni un $2 \%$ dels ingressos-; els esdeveniments, dels quals no hem pogut trobar referència sobre la importància respectiva en la seua composició dels ingressos procedents dels lluïsmes i els de les multes, tal com passa en d'altres viles; i el morabatí, no inclòs inicialment per la comptabilitat del Batlle General i que de nou hem afegit en base a la col.lecta d'aqueix impost de l'any 1415.

En resum, resta una renda procedent en quasi un $40 \%$ de la fiscalitat directa -peita i cena-, en quasi un $25 \%$ del delme i als voltants d'un terç dels diversos monopolis i regalies, inclosa l'escrivania de la Cort, de manera que la renda directa és molt més alta de la mitjana i el delme es veu minvat en el seu paper pels arrendaments dels principals monopolis.

10.- Alzira:

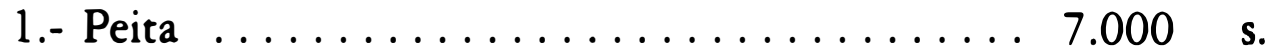

2.- Peita dels sarraïns $\ldots \ldots \ldots \ldots \ldots \ldots \ldots \ldots 100$ s.

3.- Carnisseries ................... 577 s.

4.- Forns . . . . . . . . . . . . . . . . . . 284/4 s. $/ \mathrm{d}$.

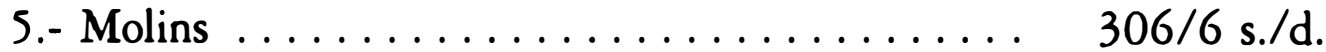

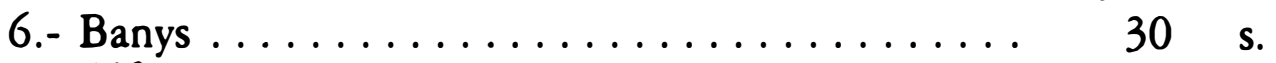

7.- Alfondec ...................... 7 s. 
8.- Censals menuts . . . . . . . . . . . . . 954/2 s. $/$ d.

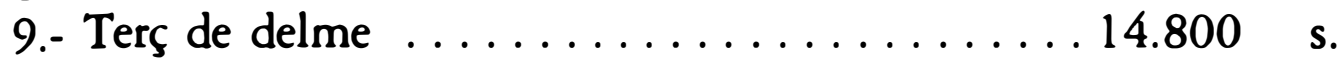

10.- Carnatge ................... 300 s.

11.- Carnisseria sarraïns $\ldots \ldots \ldots \ldots \ldots \ldots \ldots .90$.

12.- Gabella de la sal . . . . . . . . . . . . 2.000 s.

13.- Pes i almodí ................. 400 s.

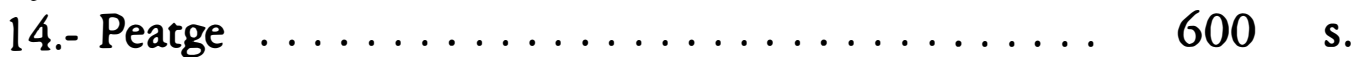

15.- Besants dels sarraïns . . . . . . . . . . . 100 s.

16.- Morabatí .................. 550 s.

28.051 s./any
(Quadre 10)

Les rendes d'Alzira a inicis del segle XV també presenten, com el cas de Morvedre, una major varietat que en indrets més menuts, així com una suma global més elevada. Les rendes fixes en diners munten fins sols un terç dels ingressos totals, la qual cosa és inferior a les proporcions més comunes en la majoria de les viles valencianes reials. La seua composició té la tradicional peita -ara sense cena- (que a soles és un $25 \%$ de les rendes totals), acompanyada per quantitats molt menors dels principals monopolis -forns, molins, carnisseries, banys, cases i terres-, els quals s'hi troben establerts a cens fix en diners $i$ tots junts volten un $8 \%$ dels ingressos comuns.

Entre els monopolis $\mathrm{i}$ «censals menuts», hem aconseguit destriar cadascun dels apartats; paguen censos anuals en diners els següents:

- 68 obradors $728 / 6$ s./d.

- 10 carnisseries 577

- 15 molins $306 / 6$

s.

- 17 forns $284 / 4$

- 31 cases $218 / 2$

- 11 parcel.les de terra. 83 s./d.

- 1 banys 30 S.

- 1 alfondec $7 \mathrm{~s}$

- 1 forn de cànters $3 / 4$ s. $/$ d.

- 1 casa de la cort i presó 3 s.

\section{$2.240 / 10 \mathrm{~s} . / \mathrm{d}$.}

${ }^{13}$ La font emprada correspon al llibre esmentat del Batlle General (ff. 58 r.-105 v., i també un resum als ff. 227 r.-228 v.). Les notícies que dóna procedeixen del batlle local, el qual envià un detallat informe al Batlle general del regne amb els comptes dels anys $1408 \mathrm{al}$ 1412; la comptabilitat seriada conservada a l'arxiu del regne de València referida a aquest batlle local no comença fins el 1431 (ARV, MR, núm. 923). 
Com pot veure's, i a diferència de Morvedre, el que la quasi totalitat dels monopolis estiguen establerts i no arrendats implica una caiguda molt forta dels ingressos corresponents; a més, això du al fet que la part més forta d'aquests "censals menuts" procedeixca dels censos dels obradors urbans, mentre que els molins o els forns signifiquen al voltant d'un 12 o $13 \%$ tan solament d'aquest apartat i al voltant d'un $1 \%$ dels ingressos totals extrets del lloc. En la seua gran majoria s'hi troben a la mateixa vila d'Alzira o al seu raval, llevat dels molins, forns i carnisseries, els quals trobem repartits pels diversos llocs inclosos en el terme general d'Alzira: Carcaixent, Algemesí, Guadassuar, Benimaclí, Ternils, Cogullada, El Toro, Cabanes i Campanar.

Quant a les rendes variables per ser arrendades anual o bianualment i que en conjunt són sobre $3 / 4$ parts del total, la part més forta claríssimament procedeix del terç de delme: entre tots els seus apartats suma sobre un $55 \%$ de les rendes d'Alzira.

Hi ha tres monopolis que també eren arrendats anualment - la gabella de la sal, el pes i almodí del mercat, i la carnisseria del raval sarraí, amb un valor aproximat tot de 2.490 s. - un $9 \%$ de les rendes totals-, i resta en el llistat un breu apartat sobre la renda comercial típica, el peatge, el qual sols significa sobre un $2 \%$.

Els llistats d'Alzira donen el valor aproximat del besant en aqueixos anys, uns mísers 90 s., però en canvi no donen la xifra del morabatí. Hem trobat la data corresponent en altres tipus de fonts per a aqueixos anys, amb un valor de 800 focs, però en canvi la tatxa del braç reial del periode 1404-1409 aporta el valor de 342 focs fiscals per a Alzira; no resulta facil aclarir sense més aquesta quantitat i n'hem decidit posar el valor mitjà entre elles; si més no, ens indica que el possible valor econòmic -i percentual- del morabatí no devia afectar molt les proporcions dels ingressos de la monarquia en conjunt.

Així mateix no apareixen inclosos en el llistat elaborat pel Batlle General els apartats de lluïsmes $i$ esdeveniments amb el sentit que hem trobat en anteriors pobles. Atesa l'extensió d'Alzira així com el nombre elevat d'obradors i monopolis a cens, cal valorar com no menyspreables els ingressos per lluiismes, i semblant consideració, encara que més irregular i reduida, podria fer-se sobre els ingressos reials procedents de les multes dels oficials locals. En tot cas i considerant la manca de fonts sobre el tema per a aquest període, cal acceptar com raonablement aproximades les xifres aportades.

$$
\text { 11.- Cullera: }
$$

1.- Peita ......................2.500 sous

2.- Cena ..................... 250 s.

3.- Censals menuts ................... 220 s.

4.- Terç de delme ................ - 
5.- Carnisseria ................. -

6.- Setzena del peix del riu ............. -

7.- Pont del riu .................... $600 \mathrm{~s}$.

3.570 s./any

El cas de Cullera és especial en el context valencià en raó de faltar una part important dels ingressos entre la documentació existent; això fa difícil de calibrar i jutjar la tipologia de la renda; sense el valor aproximat del terç de delme resulta aventurat fer comentaris en conjunt. Sols cal subratllar que la fiscalitat fixa directa - peita i cena- no és de les més baixes en el conjunt del regne, $i$ que els censals menuts es troben dins d'uns valors més aviat baixos tenint en compte que no apareix cap menció a forns o molins com a apartats separats $i$ que, els que n'estigueren a cens, haurien d'estar inclosos entre aqueixos «censals menuts».

També cal subratllar l'ingrés "pont del riu», entès com un peatge i per tant de caire comercial, el qual es troba en els nivells més o menys semblants dels peatges de les grans viles valencianes que hem vist fins ara -Alzira 0 Morvedre-, però que com a tal no és de les rendes més comunes a tots els llocs; el mateix passa amb aqueix desconegut «setzena del peix del riu», el qual deu ser semblant al «quint del peix de l'Albufera» existent entre les rendes de la ciutat de València; no tenim indicis del seu valor però, sense ser exagerats, podem aventurar que devia tenir un nivell mitjà en el conjunt de les rendes de la vila.

\section{2.- Xàtiva:}

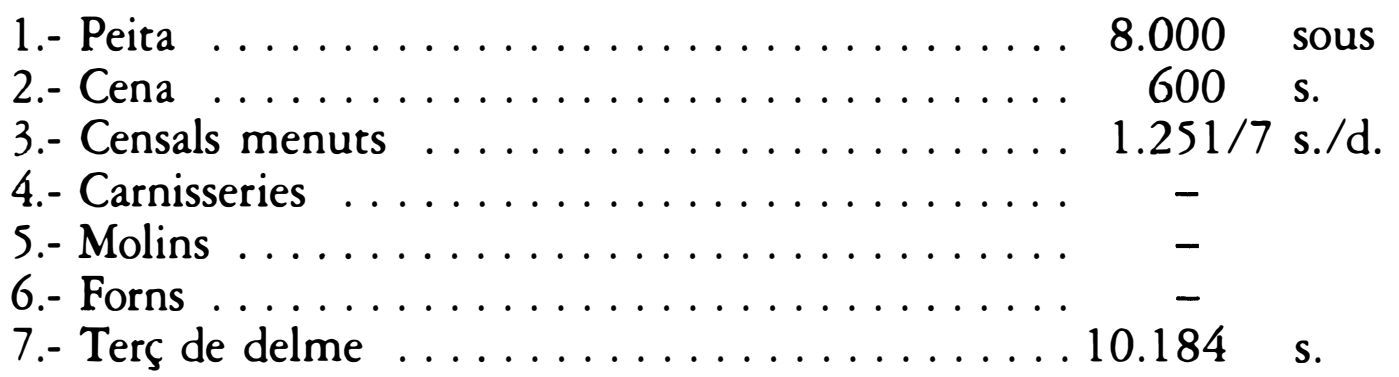

14 Les fonts sobre Cullera han estat les més reduides de tots els pobles; sols apareix la seua relació en el llibre del Batlle General (ff.56 r.-57 v.), molt incompletes, i no hi ha comptabilitat sobre aquesta vila en els llibres del Mestre Racional. Potser tinga a veure amb cert establiment de les rendes de la vila en el seu favor, fet pel rei Martí a inicis d'aquest segle $\mathrm{XV}$. 


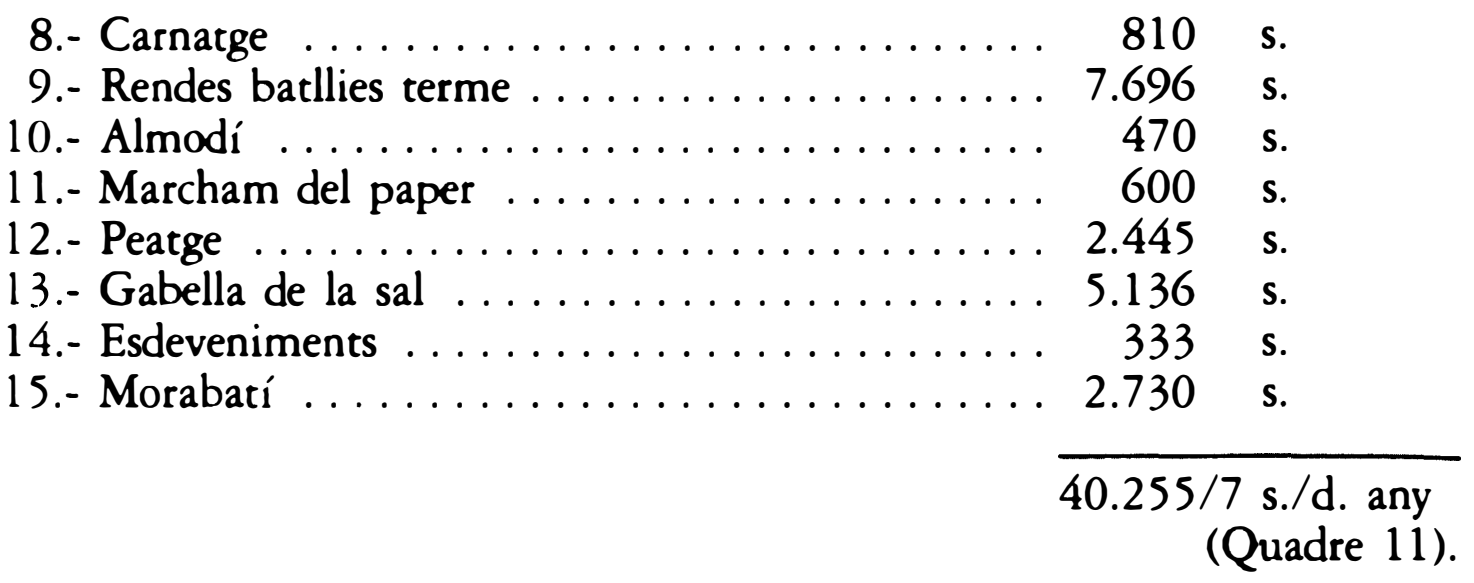

Moreria de Xàtiva:

1.- Peita

$2.500 \mathrm{~s}$

2.- Trahut $500 \mathrm{~s}$.

3.- Alfondec $800 \mathrm{~s}$.

4.- Forns $312 \mathrm{~s}$.

5.- Dret de la cera $102 \mathrm{~s}$.

6.- Dret del sabó $440 \mathrm{~s}$.

7.- Banys $1.440 \mathrm{~s}$.

8.- Pes real $480 \mathrm{~s}$.

9.- Obradors dels albardaners ............. 440 s.

10.- Tintoreria . . . . . . . . . . . . . . . . 480 s.

11.- Carnisseries . . . . . . . . . . . . . . . 1.885 s.

12.- Besants . . . . . . . . . . . . . . . . $1.350 \mathrm{s.}$

13.- Tarquena .................... 330 s.

14.- Debeha ..................... 342 s.

15.- Mealles ..................... 360 s.

16.- Herències dels moros . . . . . . . . . . . . $400 \mathrm{~s}$.

$12.161 \mathrm{~s} /$ any

(Quadre 12).

Suma total Xàtiva i moreria:

52.416 s/any $^{15}$

15 Les rendes de Xàtiva apareixen detallades en el llibre del Batlle General (ff.110 r.-120 v.), on consta la comptabilitat del seu batlle local entre 1410 i 1413 . També inclou un llistat amb les rendes alienades a diversos monestirs i particulars i que, així, no cobra ja el dit batlle; també els comptes del batlle local a ARV, MR, n. 3016- 3018. 
Xàtiva és la ciutat més gran del regne de València després de la seua capital, i també té la moreria urbana de major demografia a inicis del segle XV. Això fa que el llistat de les seues rendes siga llarg i detallat, a més de presentar la tipologia de rendes sobre una comunitat islàmica, la qual, en tot cas, no és la més comuna al model de les aljames sarraïnes valencianes ja que es tracta d'una moreria urbana i no rural.

El conjunt d'ambdues comunitats és el de renda més elevada de totes les batllies locals, i també ho és el de la Xàtiva cristiana a soles. En aquesta, les rendes fixes conegudes signifiquen quasi la quarta part de la renda reial, en bona mesura procedent de les tradicionals peita i cena -sobre un $21 \%$ del total-. Sols un $3 \%$ procedeix dels "censals menuts», els censos anuals en diners pagats per cases, terres i obradors; no hem pogut trobar un quadern d'aquests anys que donara llum sobre la composició exacta d'aqueixos béns emfitèutics en mans reials, però quan els comparem amb les quantitats d'altres viles ens adonem del seu gran nombre ja que la xifra és molt elevada. Més encara quan fora d'aqueixa quantificació han quedat les carnisseries, molins i forns, establerts a cens en temps passats i dels quals no hi ha hagut manera de trobar el valor; segons el llibre del Batlle General de 1414, els censos de les carnisseries els rebia directament el convent de Santa Magdalena de Montsant, de la ciutat de Xàtiva, i el mateix feïa amb censos en diners $\mathrm{i}$ espècie de molins $\mathrm{i}$ molts forns $\mathrm{i}$ també de terres amb el seu corresponent terç de delme, les quals es trobaven a l'horta de Xàtiva, a la partida «de les dones» ${ }^{16}$.

Feta aquesta salvetat, difícil d'avaluar, la renda variable en funció de ser arrendada periòdicament arriba a quasi 3/4 del total. En aquesta el terç de delme és clarament dominant -sobre un $27 \%$ sols per al terme estricte de Xàtiva-, i molt més elevat si sumem l'apartat dels ingressos de les quatre batllies menors corresponents a l'Olleria, Benigànim, Castelló de Xàtiva i l'Enova. En aquest darrer cas es tracta d'unes entrades procedents probablement de totes les rendes comunes a cadascuna d'aqueixes viles, per la qual cosa hi deuen ser compresos no sols el terç de delme local sinó també els monopolis, els quals potser foren elevats. Amb tot, si juntem terç de delme de Xàtiva i rendes de les batllies locals menors, sumen quasi prop de la meitat dels ingressos d'aquesta batllia.

El delme apareix cobrat sobre el llistat de productes tradicionals, majoritàriament els cereals (delme del pa), i sobre el vi, oli, hortalissa, animals $i$, cas

${ }^{16}$ Hem pogut trobar que va ser el rei Pere el Cerimoniòs qui a mitjan segle XIV, havia donat tots aquests censos al dit convent, però en un moment anterior als primers llibres de comptabilitat del batlle local conservats a l'arxiu del Regne de València, any 1382 (ARV, MR, n. 3.011). 
peculiar, la fulla de les moreres malgrat que amb un valor força baix -160 s./any, sols el 1 ' $6 \%$ del valor de tot el delme-.

Entre la resta de rendes variables destaca també algun ingrés especial pel seu valor: la gabella de la sal per si a soles val vora un $13 \%$ del total, i l'única renda estrictament comercial, el peatge que trobem a les grans viles reials, ací significa un $6 \%$ malgrat que, quantitativament, és el més alt després dels impostos comercials recaptats a la ciutat de València -2.445 sous-.

Resten un parell de monopolis que eren arrendats periòdicament -cas de l'almodí o monopoli en la venda de cereals panificables dins la vila- així com un altre que no existeix per enlloc: el "marcham del paper», sens dubte la renda cobrada per la fabricació artesanal d' aquest producte; tot junt, però, no arriba a un $3 \%$ de les rendes de la Xàtiva cristiana. Finalment ocupen un lloc en els llistats de la batllia els esdeveniments i el morabatí; sobre el primer la quantitat ací posada és baixa i, pel que hem pogut comprovar en veure més anys, devia trobar-se més facilment en aquests anys entre 500 i 1000 sous, però hem mantingut aqueixa xifra perquè correspon als comptes de l'any $1410 \mathrm{i}$ hem preferit respectar l'homogeneïtat proporcional de les dades entre tots els apartats malgrat les fluctuacions que hi ha d'any en any perquè per la resta de rendes no podíem traure mitjanes.

És paregut el que passa amb el morabatí, el qual és inclòs com a apartat dels ingressos però no s'hi indica cap quantitat; seguint el sistema de cobrar o comptabilitzar un sou per foc anual, Xàtiva devia pagar en aqueixos anys de 2700 a 2800 sous en base a les xifres de la tatxa del braç reial de 1406-1410 i el morabatí de 1415 , respectivament, però no és possible assegurar-ho amb més detall ara per ara. No és una quantitat baixa -sobre un $7 \%$ de les rendes ordinàries que hem detallat abans-, i la seua variació modificaria un poc totes les proporcions $\mathrm{i}$ tants per cent que n'hem fet fins ara.

Les rendes de la moreria de Xàtiva són clarament diferents a les de la ciutat cristiana, però tampoc no són les més típiques de la gran majoria de les aljames sarraïnes del Regne. A cop d'ull pot veure's que la nomenclatura de la seua fiscalitat és radicalment distinta, en bona mesura d'origen islàmic; també pot veure's que molt majoritàriament en nombre i quantitat són impostos que són arrendats periòdicament -quasi un $70 \%$ ho són-i que no hi ha rendes per la terra en principi. Les rendes fixes anuals són sols les de la fiscalitat directa -peita i traüt, i el cens de l'alfondec, elevadíssim per altra part en comparació a la resta de pobles valencians. ".

La renda variable consta dels tradicionals monopolis de forns, banys $\mathrm{i}$ carnisseries -tots dos darrers molt elevats-, obradors, tintoreria i dret de la fabricació de la cera i del sabó; tot just representava sobre un $42 \%$ de les rendes

1) Sobre la renda feudal a les aljames valencianes medievals, vegeu E.Guinot, 1992 b. 
de la moreria i pot assenyalar-se no sols el seu molt elevat valor quantitatiu sinó que, en part destacada, són monopolis sobre activitats productives artesanals, la qual cosa no és gens freqüent en el cas de les aljames sarraïnes; la manca de rendes per la terra és també causa d'aquesta importància proporcional dels monopolis.

Resten finalment dos apartats: la renda dels besants, capitació pagada pels moros $i$ que fluctuava en base a la demografia -ací prou alta com podem veure-, $\mathrm{i}$ un darrer bloc de rendes tradicionals de les moreries valencianes medievals: la tarquena, la debeha, les mealles i les herències dels moros - valor dels béns que té dret a quedar-se la monarquia quan mor un musulmà sense hereus directes a la vila-, les quals munten poc més del $10 \%$ de les rendes totals de la moreria.

En resum, Xàtiva presenta algunes peculiaritats en les seues rendes, fruit de la seua importància i de la seua elevada població; el balanç no eleva molt la fiscalitat directa -peita i cena-, ja que ve a ser d'un $23 \%$ del total d'ambdues comunitats de Xàtiva; el bloc del terç de delme, en canvi, és més important i arriba a un $37 \%$ d'aqueix mateix total, mentre que els monopolis en les seues diverses variants volten sobre un $25 \%$ i les rendes del comerç -peatge i pes reiales limiten a un $6 \%$. La resta està formada per les reduïdes rendes exclusives dels musulmans -besant, etc. $-\mathrm{i}$ pels apartats dels esdeveniments. Cal subratllar una vegada més les diferències entre cristians i sarraïns quant la situació dels monopolis, donats en emfiteusi o alodials en el primer cas, mentre que sempre són arrendats en el segon, i així són també molt més rendibles per a la senyoria.

\section{3.- Ontinyent:}
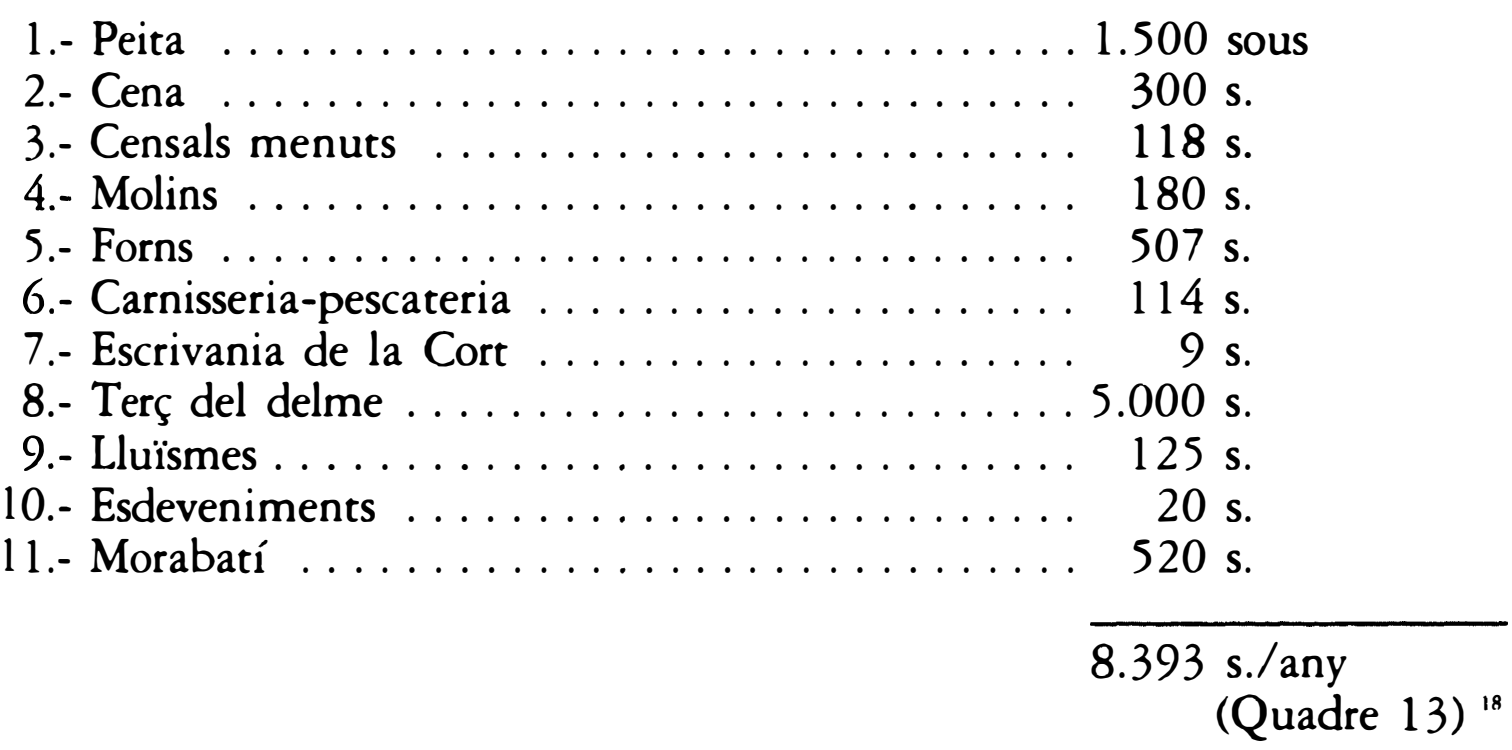

18 Les fonts són el llibre del Batlle General de 1414 (ff. 121 r.- 124 r. i ff. 418 r.-425 
Les rendes de la batllia d'Ontinyent són molt majoritàriament de caràcter fix en la seua tipologia, que no tant en el seu valor; tant la peita com la cena i tots els monopolis possibles -11 molins, 4 forns, 4 carnisseries i l'escrivania de la Cort del Justícia a la mateixa vila d'Ontinyent, $\mathrm{i}$ un altre forn i carnisseria al veí lloc d'Agullent-, a més dels anomenats censals menuts -censos per 16 cases i 10 parcel.les de terra-, tenen aqueix caràcter i munten un terç de la renda total (32' $5 \%$ ); el altres dos terços fluctuen en funció de l'arrendament periòdic del terç de delme -sens dubte l'ingrés fonamental de la monarquia a Ontinyent-, el qual puja a vora el $60 \%$ del total, i els ingressos irregulars de les multes del mostassà i Justícia local, dels lluïsmes dels béns emfitèutics que tenia el rei a la vila i de la fiscalitat del morabatí.

Aquest model amb peites sempre més baixes davant un terç de delme dominant, és de nou el més general en aquestes viles de la meitat sud del país que veurem a partir d'ara. ¿Caldria cercar les raons en els anys del repoblament, quan es devien fixar unes rendes més baixes per a aquestes viles de frontera? $\mathrm{Si}$ més no, cal també tenir en compte que Ontinyent és la vila més gran al sud de Xàtiva i fins a Oriola.

14.- Biar:

1.- Censals menuts ................... 109 sous

2.- Escrivania de la Cort .............. $50 \mathrm{s.}$

3.- Carnisseries ................... $18 \mathrm{s.}$

4.- Terç de delme ..................2.500 s.

5.- Molins ..................... 258 s.

6.- Forn .................... 349 s.

7.- Llü̈smes .................... $100 \mathrm{s.}$

8.- Esdeveniments ................ $27 \mathrm{~s}$.

v.) i també els comptes del batlle local dels anys 1414 a 1422 (ARV, MR. núm. 4351-4352). Les dades del morabatí procedeixen de la mitjana de focs fiscals entre la tatxa del braç reial de 1404-10 i el morabatí de 1415.

19 La font fonamental ha estat el llibre del Batlle General de 1414 (ff.125 r-130 v, f. 347 r., i ff. 428 r- 434 v), on apareix la comptabilitat del batlle local dels anys $1391 \mathrm{i}$ 1411-1412. Al mateix arxiu (MR, núm. 4351), corresponent a la batllia d'Ontinyent, també s'hi troben els comptes del batlle local de Biar -és el mateix personatge- per als anys 1414 a 1416, la qual cosa permet completar les dades anteriors i, en concret, el valor del terç de delme. La comptabilitat seriada de la batllia de Biar no comença a l'Arxiu del regne de València fins el 1468. 
Sobre les rendes de Biar a inicis del segle XV, el primer que crida l'atenció és l'absència d'impostos directes com la peita i la cena; no hem pogut esbrinar per què i des de quan no es paguen, però cal suposar algun enfranquiment en temps passats. Això fa que la composició de la seua renda siga especial, amb un valor força reduit dels ingressos fixos anuals al voltant del $5 \%$ i limitats a alguns dels monopolis -l'escrivania de la Cort i dues carnisseries- $i$ als anomenats censals menuts rebuts per 34 parcel.les de terra.

El cos de la renda procedeix de l'arrendament anual del terç de delme, el qual munta les $3 / 4$ parts del total d'ingressos, acompanyat a molta distància dels forns i molins -un 18' $5 \%$-. Entre aquests darrers no tots són arrendats sinó que en part també estan establerts a cens fix anual; en concret, hi havia a Biar 1 forn a cens i un d'altre d'arrendat, i 7 molins a cens fix en diners i 4 més de sotmesos a cens en espècie, fluctuant el valor de venda del gra corresponent.

La renda es veu complementada pels menuts ingressos procedents dels lluïsmes i de les multes del mostassà i Justícia local. No hem pogut trobar cap rastre del pagament del morabatí a Biar, la qual cosa fa sospitar si no en fóra exempta; aquest fet juntament amb l'absència de la peita ens fa pensar en un cas una mica especial de franqueses fiscals, potser per problemes de poblament a partir de la guerra de Castella a mitjan segle XIV -en tot cas, a finals del segle XV tampoc n'eren pagats, tal com pot veure's als comptes del batlle local-.

15.- Xixona:

1.- Peita ...................... 300 sous

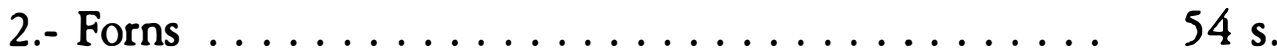

3.- Molins .................. $24 \mathrm{~s}$.

4.- Carnisseries .................. $14 \mathrm{s.}$

5.- Escrivania de la Cort ............... 7 s.

6.- Censals menuts ............... $31 \mathrm{~s}$.

7.- Terç de delme .................1.170 s.

8.- Morabatí ...................... 120 s.

9.- Esdeveniments ................ -

$1.720 \mathrm{~s} . /$ any

(Quadre 15) ${ }^{20}$.

${ }^{20}$ Les fonts sobre Xixona són de les més escasses del conjunt de viles reials valencianes. El llibre del Batlle General sols fa una anotació del seu trellat teòric (f.239) -el qual mantenim en el quadre adjunt núm. 15-, però no inclou comptabilitat concreta de cap any. 
Les rendes de Xixona són francament reduïdes, en la qual cosa té a veure tant l'escàs valor de les rendes directes - una peita baixa i l'absència de cenacom un terç de delme també reduït, probablement en relació amb la poca demografia del lloc-sobre uns 120 focs fiscals com mitjana entre els 105 de la tatxa de 1404-1410 i els 134 del morabatí de 1415 .

A Xixona, si la peita és reduiida, també ho són els ingressos pels diversos monopolis, els quals s'hi troben tots establerts a cens emfitèutic fix: forns, carnisseries, molins, unes poques parcel.les -censals menuts- $\mathrm{i}$ l'escrivania de la Cort, tot junt $130 \mathrm{~s}$. i sobre un $7.5 \%$ del total. Com dèiem, el terç de delme és el component dominant, amb dos terços del total, i la resta està formada per la peita i pel morabatí. Els apartats tradicionals dels esdeveniments i lluïsmes no són ací mencionats i no tenim referències del seu possible valor però, atès el tipus i situació de les regalies i el nivell demogràfic de la vila, tot fa suposar que es tractava de quantitats molt reduïdes, fins $\mathrm{i}$ tot freqüentment nul.les.

16.- Penàguila:

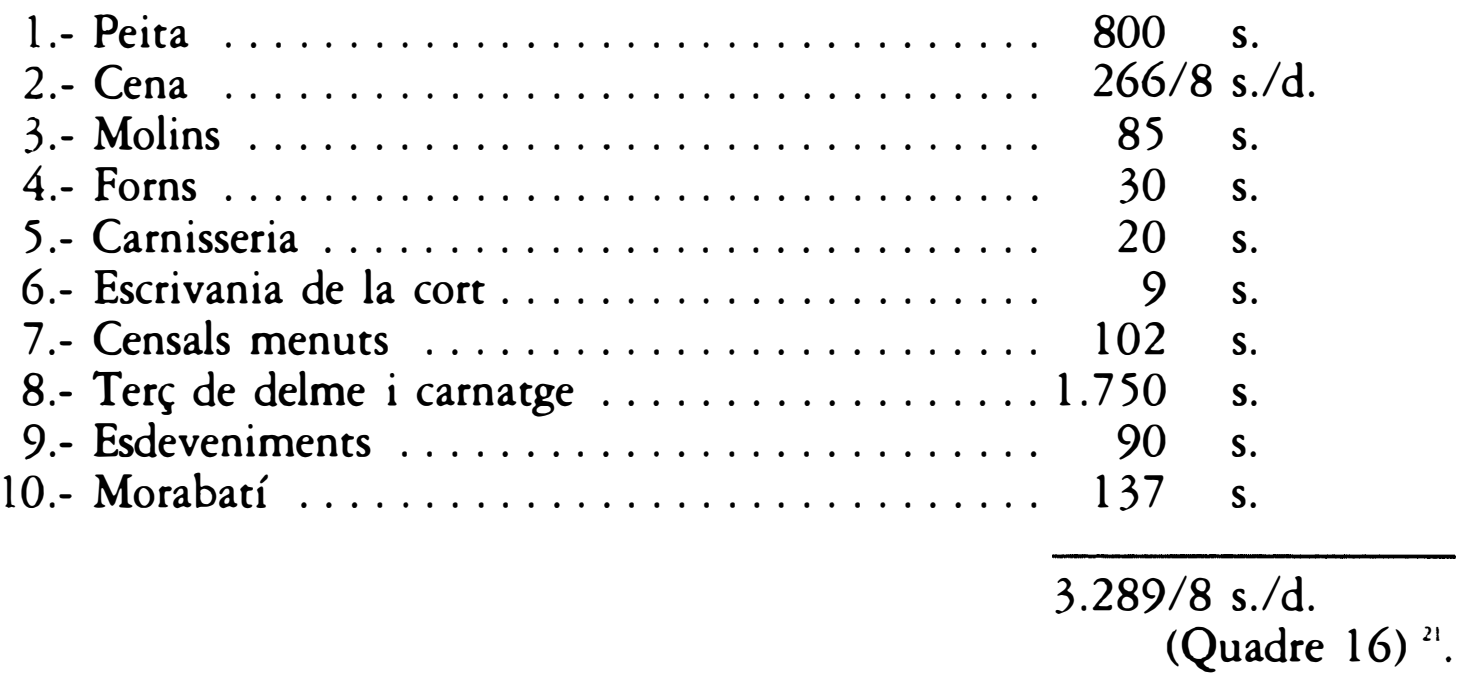

A més, entre els comptes del Batlle General del Regne (ARV, Batllia, núm. 32 a 36), corresponents als anys 1412 a 1416, hi apareix una anotació sobre l'arrendament global de les rendes de Xixona fet per aquest personatge durant aquests anys; probablement això estiga en relació amb el fet que no hi ha comptabilitat pròpia del batlle local fins el 1468 (ARV, MR, núm. 3372).

2 La font sobre les rendes de Penàguila ha estat el llibre del Batlle General en 1414 (f. 109 r., f. 327 r. i ff. 437 r. -440 v.), on hi ha dos quadres amb les rendes aproximades teòriques d'aquesta vila $\mathrm{i}$ el detall de la comptabilitat general en els anys 1413 i 1414. La dada variable del terç de delme l'hem treta fent la mitjana entre ambdós anys. Hem completat la informació amb la comptabilitat del batlle local dels anys 1419 a 1421 , primer 
Les rendes de Penàguila mostren els trets del model més comú de les viles valencianes, encara que tot dins uns àmbits reduïts i de poc volum, lligat això al dèbil poblament que anem constatant per a totes les viles meridionals del regne quan començava el segle XV.

Les rendes fixes tenen la seua base en la peita i la cena -un $33 \%$ del total-, acompanyades de tots els monopolis, els quals també estan donats a censos fixos: 4 molins, 2 forns, l'escrivania de la Cort, 4 cases, 1 obrador, la carnisseria-pescateria i 13 parcel.les de terra; tot junt munta 246 sous 10 diners, però amb un valor proporcional de sols el $7.5 \%$.

La renda variable d'any en any és de quasi el $60 \%$, amb base fonamental en el terç de delme i carnatge, com per tots els llocs; ací significa el $53 \%$ del total, i la resta a repartir entre el morabatí i els esdeveniments. Aquests inclouen tant la part reial de les multes locals com els lluïsmes; fluctuen molt d'any en any -per la qual cosa hem posat la mitjana dels anys coneguts- $i$ en aquest cas procedeix quasi totalment dels lluïsmes dels béns emfitèutics venuts pels veïns.

\section{7.- Alacant:}

Les rendes d'Alacant, juntament amb les d'Oriola, Elx i Guardamar, apareixen també en el manuscrit del Batlle General de 1414, però amb una peculiaritat molt important. Els comptes que copia (f. $\left.300 r^{\circ}-310 r^{\circ}\right)$ corresponen als anys 1317 a 1322 i procedeixen, tal com s'hi assenyala, dels llibres de comptabilitat conservats a l'arxiu reial de Barcelona, d'on trau la informació. No inclou el llibre, però, cap informació sobre el valor i contingut de les rendes en el moment de la seua redacció, un segle després a les dades que aporta sobre Alacant en concret; el problema continua quan anem a la comptabilitat del batlle d'Oriola-Alacant a inicis del segle XV, teòricament conservat a l'arxiu del Regne de València (A.R.V, M.R., n.4547 i 4548), i ens trobem que no hi consta cap informació sobre Alacant; allí sols hi ha les dades de la batllia d'Oriola.

La tipologia de les rendes a inicis del segle XIV sempre podrien ser un indicatiu de la seua composició i valor, però difícilment extrapolable a un segle després. Caldrà, doncs, esbrinar les raons d'aquesta absència en la comptabilitat reial d'inicis del segle XV i fins quin punt respon a una pèrdua documental o respon a una realitat de les, sembla, molt grans dificultats d'aquesta vila en aqueixos anys; amb una demografia molt baixa, sabem que Alacant tingué

quadern conservat. (ARV, MR, num.4715). Les seues dades són semblants a les anteriors però han permés conèixer al detall els censos en diners $\mathrm{i}$ nombre de monopolis i regalies existents. La dada del morabatí procedeix dels comptes de la seva col.lecta de 1415 . 
dificultats grans per fer cara a diversos impostos extraordinaris -en 1415 Ferran I absol Alacant del pagament de subsidi extraordinari per a la guerra de Sardenya, en raó de la seua pobresa (A.R.V., M.R. n.36, f.86)-.

\section{8.- Oriola-Guardamar:}

1.- Censals menuts terme $\ldots \ldots \ldots \ldots \ldots \ldots \ldots 532 \mathrm{~s}$.

2.- Censals menuts raval ................. 277 s.

3.- Almoxerifat .....................435 s.

4.- Coses vedades ................ 88 s.

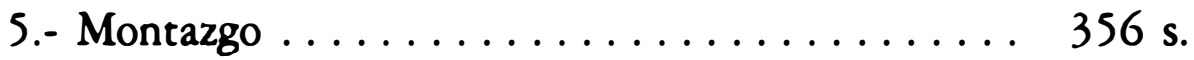

6.- Pesqueres ................... 975 s.

7.- Salines Guardamar ................ 666 s.

8.- Escrivanies de les Corts ............... 1.673 s.

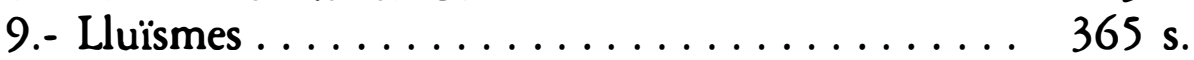

10.- Cavalcades en la mar ............... $1.050 \mathrm{~s}$.

11.- Multes i guiatges moros .............. $583 \mathrm{s.}$

12.- Multes cristians . . . . . . . . . . . . 226 s.

$8.216 \mathrm{~s}$.

(Quadre 17) ${ }^{22}$.

La renda d'Oriola presenta característiques pròpies evidents respecte a la resta de viles valencianes. Sens dubte cal trobar aqueixes diferències en l'origen del repoblament castellà del segle XIII, el qual va marcar uns mecanismes d'exacció fiscal i de franqueses impositives diferents als de la tradició catalanoaragonesa de la resta del país. Això fa que no trobem per enlloc ni la fiscalitat directa de la peita i cena, ni el component majoritari de la resta de llocs, el terç de delme o les seues variants.

Com podem veure al quadre 17 , les rendes fixes es limiten als censos emfitèutics d'una sèrie de monopolis i també d'algunes cases i terres. Sols hem trobat en la documentació el detall de censos del primer bloc, els «censals menuts del terme», i que corresponen als que eren cobrats pel Batlle General d'Oriola tant en aqueixa vila com a diversos pobles del seu terme general; el

${ }^{22}$ La font sobre les rendes d'Oriola procedeix dels llibres de comptabilitat del Batlle general d'Oriola, dels anys 1413 a 1416 (ARV, MR, núm. 4547), on detalla les entrades per cadascun d'aquests apartats; en els casos de les multes $\mathrm{i}$ cavalcades les enumera individualment $\mathrm{i}$ hem procedit a la seua suma per temes. Les dades numériques corresponen a la mitjana dels anys consultats -1413 a 1416-, amb l'intent així que les proporcions relatives d'un ingrés $i$ altre siguen les més aproximades. 
segon bloc -de 277 s. anuals- era cobrat pel batlle local d'Oriola, sense que a la documentació aparega el detall dels pagaments; l'única indicació és que es tractava de cases i terres situades al raval de la vila d'Oriola, on havia estat la moreria en temps passats.

Així doncs, el resum dels censos coneguts del terme d'Oriola és el següent:

- 8 molins . . . . . . . . . . . . . . . 138 s.

- 16 obradors ..................... 101 s.

-10 forns $\ldots \ldots \ldots \ldots \ldots \ldots \ldots \ldots \ldots \ldots$ s.

- 8 cases .....................81 s.

- 2 parcel.les terra ................63 s.

- 2 carnisseries .................. 50 s.

$532 \mathrm{~s}$.

La resta de rendes d'Oriola, el $90 \%$ del total, procedeix de les rendes fluctuants d'any en any en funció del seu arrendament o del seu valor irregular perquè són multes $o$ ingressos comercials.

També aquest apartat és molt diferent al model comú valencià; l'esmentada absència del terç de delme no és l'única important peculiaritat; les rendes comercials tenen un major pes - l'almoixerifat i les coses vedades signifiquen un 18' $5 \%$ dels ingressos- $\mathrm{i}$ també el tenen els monopolis per a l'explotació de recursos naturals com ara el montazgo -pagament per l'ús de les pastures per part dels ramaders castellans-, les salines de Guardamar i les pesqueres del cap de l'Anguella -dret de peixcar a la mar i pagament pel peix cobrat-; tots tres monopolis són arrendats en subhasta pública per períodes de 2 a 3 anys $i$ muntaven en conjunt una mitjana del $24 \%$ dels ingressos de la batllia.

El mateix caràcter especial es veu en els forts ingressos de caràcter jurisdiccional i extraordinari com són les multes judicials, tant a cristians com sarraïns, els ingressos per la venda de moros esclaus, els guiatges i permisos d'acaptar, etc., a més de les anomenades "cavalcades de la mar», això és, que la monarquia es queda 1/12 part dels ingressos procedents de la venda en subhasta pública dels béns i esclaus conseguits per les naus que anaven en cors $i$ venien després el botí a Oriola; la quantitat per tots aquests aspectes ve a ser d'un $22 \%$ però el que més de la meitat vinga dels guanys del cors palesa l'especial origen dels ingressos reials a Oriola.

Resten finalment uns ingressos també significatius procedents dels monopolis: al $10 \%$ dels censos emfitèutics cal afegir el valor dels lluïsmes i també el preu dels arrendaments de les escrivanies de les tres Corts que hi havia a Oriola; aquest darrer apartat és molt irregular en comparació a la resta del país ja que allò més comú era que algun notari tinguera l'escrivania a cens; ací veiem 
traure a subhasta totes tres en 1416: les del Batlle General d'Oriola, el batlle local i el Justícia, amb uns resultats molt elevats: un $20 \%$ de l'ingrés total i quasi un $35 \%$ entre tots aquests apartats dels béns a cens emfitèutic o arrendats $i$ els seus lluïsmes.

Ací acaben les rendes reials procedents de les diverses batllies valencianes a inicis del segle $\mathrm{XV}$, però no acaben els ingressos procedents d'allò que pot considerar-se patrimoni reial. El llibre inventari del Batlle General en 1414, que estem emprant com font bàsica, reflecteix clarament aquesta situació.

Per una banda fa esment de les viles d'Elx i Crevillent, però ell mateix es limita a incloure el valor de les rendes que hem explicat abans, corresponents a 1316-1322, un segle abans del període estudiat, i no aporta cap informació coetània sobre la situació en aqueixos dos llocs.

La raó n'és que tant Elx com Crevillent -viles de població important per altra part- han estat empenyorades a finals del segle XIV - 1391 en concret-pel rei Martí a la ciutat de Barcelona i és aquesta la que cobra i gestiona les seues rendes en aquestes dècades de la primera meitat del segle XV. Teòricament aquestes viles eren patrimoni reial, però a la pràctica són senyoria de Barcelona perquè li han estat venudes encara que siga a carta de gràcia o pacte de retrovenda. És també aquesta la raó per què Elx no apareix en els llistats de viles reials assistents a Corts en aquest període ${ }^{23}$.

En canvi, l'esmentat llibre del Batlle General sí que inclou una altra sèrie de viles i llocs amb les seues rendes però amb una peculiaritat molt clara: no són viles de reialenc sinó que reben el nom de «Antic Patrimoni», això és, el conjunt de viles que formaren la senyoria particular de l'infant Martí i la comtessa de Lluna a finals del segle XIV, arran de les seues noces, i que quan pujaren al tro foren incorporades al Patrimoni Reial -que no al reialenc-. Diríem doncs que es tracta del patrimoni personal de la monarquia, la seua senyoria privada, però que des de la realitat del segle $\mathrm{XV}$, de confusió entre hisenda i patrimoni reial, té com a resultat que aparega inventariat en aquest conjunt fet pel Batlle General del Regne; gràcies a això podem tenir molt bona informació sobre la tipologia $i$ valor de les rendes d'un grapat més de viles valencianes, rendes que, si de cas, també passaven a formar part de l'ingrés de la monarquia -encara que sols fóra teòricament perquè, en la pràctica, bona cosa del seu valor estava alienat i donat a tota mena de nobles, convents i creditors-.

Tal com ha estat explicat al principi d'aquest treball, l'Antic Patrimoni estava format per les viles i els llocs de Llíria, Sogorb i la seua moreria, Xèrica

Sobre Elx i Crevillent, senyoria de la ciutat de Barcelona, hi ha un treball de J.F. Cabestany i J. Sobrequés (1971). 
amb els llocs del seu comtat: Viver, Caudiel, Toro, Pina, Barraques i Novalitxes, i les aljames de la Vall d'Uixò, Serra d'Eslida, Castro, Vall d'Almonesir, Paterna i Benaguasil, aquesta amb la vila cristiana de la Pobla de Vallbona.

Vegem ara la composició de les seues rendes i els valors numèrics que representen -en la gran majoria d'aquestes viles, per cert, les quantitats numèriques estan arrodonides pel mateix informant, normalment el batlle local, i sols en alguns casos apareixen els valors d'un any concret, lògicament un dels últims arrendaments-.

19.- Llíria:

1.- Peita

$3.000 \mathrm{~s}$.

2.- Cena $400 \mathrm{~s}$.

3.- Molí ... $50 \mathrm{~s}$.

4.- Carnisseries $54 \mathrm{~s}$.

5.- Banys

$18 \mathrm{~s}$.

6.- Forn $9 \mathrm{~s}$.

7.- Terç de delme, almodí, 1 forn, resta de molins $(1 / 2$ moltura) i censals menuts . . . . . . . . . . . . . $7.500 \mathrm{~s}$ 8.- Pas o asadura ramats . . . . . . . . . . . . $120 \mathrm{~s}$.

9.- Esdeveniments Justícia i Mostassà locals

Les rendes de Llíria, vila que molt prompte passarà a ser de reialenc amb seient a les Corts valencianes, presenta de nou els trets bàsics de la renda a la resta del País Valencià. Una part fixa procedent de la fiscalitat directa en forma de peita i cena - quasi un terç dels ingressos reials- $i$ la resta en base a l'arrendament periòdic. D'aquesta segona part sols un mínim procedeix de les rendes fixes en diners d'alguns monopolis -1 molí, 6 carnisseries, els banys i 1 forn-, amb un valor de poc més de l' $1 \%$, i els altres dos terços tenen la seua base en el terç de delme i resta d'arrendaments que hom fa de forma comuna.

Això ha fet que no haja estat possible destriar totalment els ingressos

${ }^{24}$ La font sobre les rendes de Llíria ha estat el manuscrit inventari de 1414 , on consten les seues rendes en tres llocs diferents (f. $173 r^{\circ}$, f. $324 r^{\circ}-v^{\circ}$, i f. $453 r^{\circ}-454 v^{\circ}$ ); en tots tres casos els valors donats són prou semblants i estan arrodonits pel batlle local en donar la informació. 
procedents del terç de delme dels procedents de la mitja moltura dels molins de tot el terme i de l'arrendament d'un forn; el cas dels molins no devia ser menor ja que l'experiència d'altres viles ens palesa que aqueix ingrés en espècie és dels més fructífers quant monopolis, però el costum de Llíria era arrendar anualment o bianualment totes les rendes variables, terç de delme, molins, etc., de manera que el batlle local no gestionava quasi res directament.

Sols resta un mínim ingrés procedent del dret de pastura dels ramats forasters i els possibles ingressos del Justícia i mostassà locals en base a la part de les multes que correspon al Rei. Com ja ho hem explicat en altres llocs, aqueixos ingressos són minvats primer pel pagament de les despeses dels oficis $\mathrm{i}$ salaris corresponents, per la qual cosa és molt freqüent que siguen quasi zero o més facilment insuficients i no aporten ingrés a la monarquia; aquest és el cas de Llíria, on el batlle local, en el seu informe, explica aquesta situació i realitat.

20.- Sogorb:

1.- Peita

$4.000 \mathrm{~s}$.

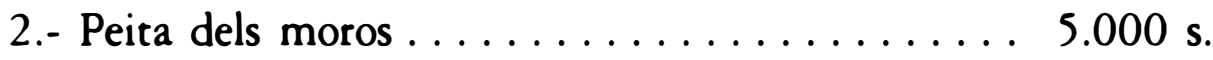

3.- Censals menuts ................. 1.325 s.

4.- Herbatge .................... 600 s.

5.- Almúnia del senyor $\ldots \ldots \ldots \ldots \ldots \ldots \ldots 100 \mathrm{~s}$.

6.- Terç de delme .................. $3.300 \mathrm{~s}$.

7.- Carnisseries .................. 300 s.

8.- Forn de la moreria ................ $600 \mathrm{s.}$

9.- Dret del mercat ................ $700 \mathrm{~s}$.

10.- Almodí .................... $500 \mathrm{s.}$

11.- Tintoreria .................... $810 \mathrm{s.}$

12.- Torçedor de la cera . . . . . . . . . . . . . 340 s.

13.- Dret de les olleries ................. 425 s.

14.- Dret de tarquena ................. 37 s.

15.- Dret d'atramussos ................. $41 \mathrm{~s}$.

16.- Dret de la pintadera ............... $11 \mathrm{~s}$.

18.293 s./any

(Quadre 19) ${ }^{25}$.

25 La font emprada és el llibre inventari del Batlle General en $1414\left(f .317 \mathrm{r}^{\circ}-\mathrm{v}^{\circ}\right)$, on apareix, en un full el llistat, net $\mathrm{i}$ ordenat en columna, de totes les rendes de la vila amb el seu valor. Considerant la claredat del compte ens hem limitat a ordenar-lo un poc. 
Sogorb és la vila més gran de les comarques interiors del centre- nord del País Valencià i seu d'un menut bisbat, amb una població mixta cristiana i sarraïna, aquesta en el seu raval urbà. Això fa que en el llistat de les seues rendes ens trobem una dualitat que s'assembla més al cas de Xàtiva, per eixemple, malgrat que ací no apareguen separades netament ambdues parts. Les rendes fixes són la part dominant, amb una forta peita que, no pas casualment, és més elevada per a la moreria que per a la vila cristiana malgrat la seua menor demografia; en conjunt és quasi la meitat de la renda total, la qual cosa no respon al model més comú que hem descrit. Algunes altres rendes fixes anuals, com ara l'herbatge, els censals menuts de monopolis, cases i terres, $i$ una heretat establerta a cens -l'almúnia del senyor-, eleven aqueixos ingressos fixos a un $60 \%$ del total.

Entre les rendes variables i arrendades periòdicament destaca, com sempre, el terç de delme, però que en aquest cas concret apareix amb una proporció molt inferior a la comuna: sobre un $18 \%$ dels ingressos totals; en canvi, el conjunt de monopolis és molt més important que a d'altres viles com a font d'ingressos, sens dubte perquè en bona part són els corresponents a la moreria i aquests no estan establerts sinó que es mantenen en règim d'arrendament periòdic; el resultat és que aquests monopolis, que en bona part graven activitats artesanals i no tan sols de consum -tintoreria, obrador de la cera, olleries, etc.-, munten un $17 \%$ de les rendes $i$, si li sumem el valor dels «censals menuts», arriben al $24 \%$ del total.

Sols restarien com a ingressos menors els de l'herbatge i el dret del mercat -un $3 \%$ o $4 \%$ aproximadament cadascun-, així com alguna renda tradicional islàmica -dret de tarquena i dret d'atremuços-, de valor econòmic mínim; en canvi, trobem a faltar en el llistat els esdeveniments amb la seua vessant dels lluïsmes, i el morabatí; els primers ja hem vist que poden no ser inclosos en el llistat del batlle o oficial perquè aquest els considere de poc valor real $i$ aleatori, la qual cosa no vol dir que no existiren; quant al morabatí, sens dubte no l'han inclós inicialment perquè era cobrat efectivament cada set anys, i no han emprat el mateix sistema comptable que en d'altres pobles; de tota manera no n'hem trobat rastre del seu valor en aquests anys per la documentació consultada.

21.- Xèrica:

1.- Peita . . . . . . . . . . . . . . . . 2.180 s.

2.- Molins . . . . . . . . . . . . . . . . . . . 3.000 s.

3.- Molí draper i tintoreria . . . . . . . . . . . . . . . $1.000 \mathrm{s.}$

4.- Escrivania de la Cort . . . . . . . . . . . . . . 200 s.

5.- Censals menuts ................... 920 s.

6.- Meitat delme . . . . . . . . . . . . . . . . $4.500 \mathrm{~s}$. 


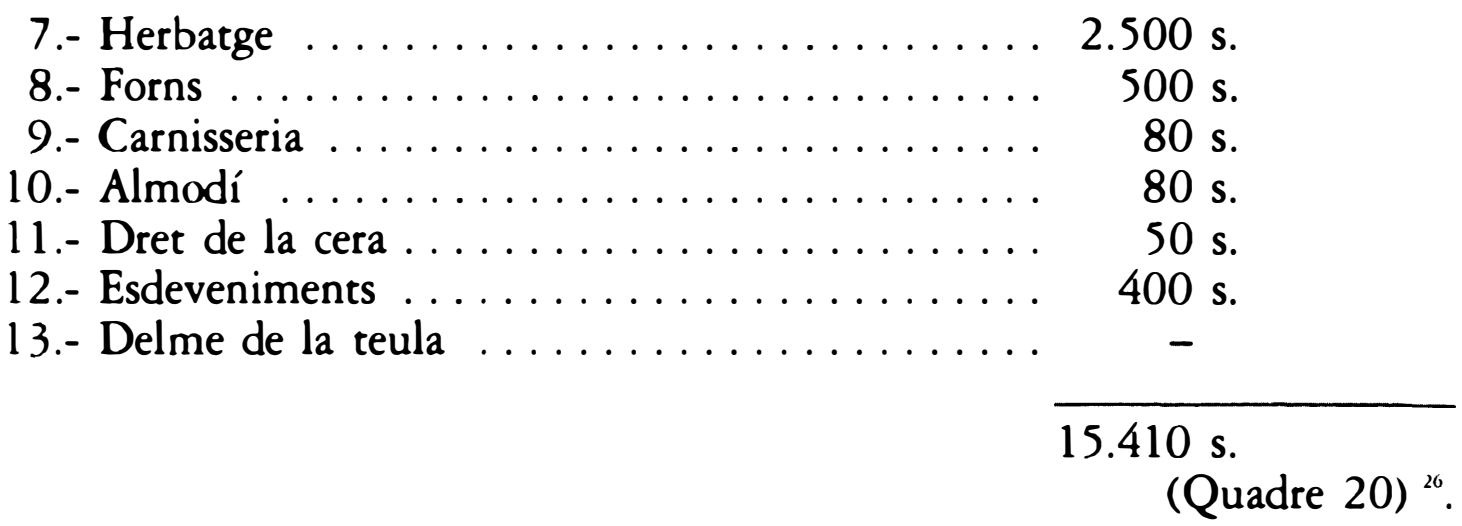

Xèrica és la vila capital d'una senyoria veïna a Sogorb i va ser senyoria del llinatge dels Xèrica durant els segles XIII i XIV. Quan les noces de l'infant Martí i la comtessa de Lluna a la darreria del segle XIV, Pere el Cerimoniòs constituí el comtat de Xèrica i els el donà, restant a partir d'aqueix moment aquesta vila de cristians així com els pobles del seu comtat dins l'anomenat «Antic Patrimoni».

Les seues rendes són quasi la meitat del seu valor de tipus fix en raó del fet que els molins pagaven una quantitat anual concreta, però per a la resta de coses és prou semblant a les que hem vist fins ara.

La renda fixa directa, la peita, no és tan important com en altres llocs -sobre un $14 \%$-, mentre que el delme -la meitat del seu valor en aquesta senyoria- puja a nivells més corrents -sobre un $30 \%$ del total; sí que crida l'atenció l'arrendament anual de l'herbatge amb un valor important -un $16 \%$ del total- $\mathrm{i}$ un ingrés individual també molt fort dels molins -un 19\%-. Aquest elevat valor individual dels diversos monopolis $i$ regalies fa que aquest bloc siga dels més importants que n'hem trobat per les viles del regne: un $38 \%$ del total. Sí que val la pena subratllar que la quasi totalitat d'aquests ingressos anuals no arribaven a mans reials, ja que hi havia una munió de consignacions $\mathrm{i}$ pensions de censals a descomptar anualment. Unes vegades eren quantitats sobre el conjunt de les rendes, però en altres casos el que s'havia fet pel rei en el seu cas havia estat donar íntegres les rendes d'alguna cosa a qui fóra -és el cas dels $3.000 \mathrm{~s}$. dels molins pagats per la vila anualment: estaven des de finals del segle XIV assignats a la cartoixa propera de Vall de Crist. En tot cas, i com fem un treball sobre la fiscalitat ordinària, hem considerat oportú incloure'l entre els llistats de rendes per veure la varietat i formes del seu gravamen -realment

26 Les fonts sobre la renda a la vila de Xèrica també es troben repetidament reproduïdes en el llibre inventari del Batlle General, on consten en diversos fulls en forma de valoracions teòriques fetes pel batlle local però coincidint en general en els seus valors. (f. 169 r.-v., f. 173 r., f. 325 r-v., f. 375 r. -376 r. i f. 443 r.-v.). 
els paga la gent-, més enllà del fet que els diners arriben al monarca o no.

Seguidament incloem el detall de les rendes dels sis llocs que conformen el terme del comtat de Xèrica en aquests anys inicials del segle XV, i que són els següents -les fonts són els mateixos folis i/o següents del cas anterior de la vila de Xèrica ja que foren inventariats tot seguit-:

Pina:

1.- Peita $537 / 4$ s./d.

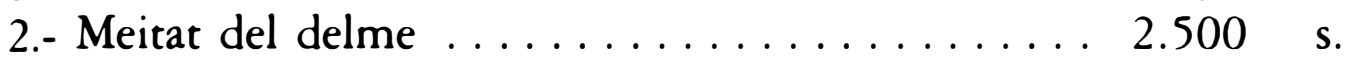

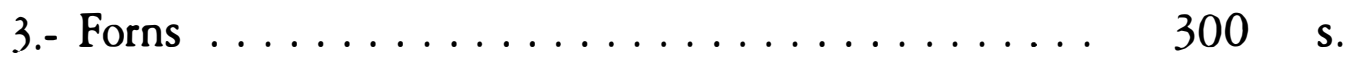

4.- Carnisseria ................... 20 s.

$3.357 / 4 \mathrm{~s} . / \mathrm{d}$.

Sant Pere de Bellmunt o Barraques:

1.- Peita

2.- Meitat del delme

$213 / 9$

3.- Forn 213 s.

4.- Carnisseria 185 s.

$20 \mathrm{~s}$.

$818 / 9$ s./d.

El Toro:

1.- Peita . . . . . . . . . . . . . . . . . . . . . . 1.040 s.

2.- Meitat del delme . . . . . . . . . . . . . 3.500 s.

3.- Herbatge ... . . . . . . . . . . . . . . . . $1.200 \mathrm{s.}$

4.- Forn . . . . . . . . . . . . . . . . . 300 s.

5.- Carnisseria .................... $30 \mathrm{s.}$

$6.070 \mathrm{~s}$.

Viver:

1.- Peita . . . . . . . . . . . . . . . . . . . . . . 5.000 s.

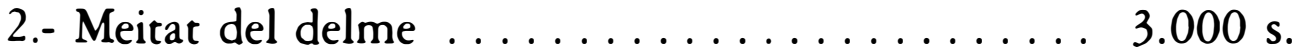

3.- Molí . . . . . . . . . . . . . . . . . . . . . 2.000 s.

4.- Forn ...................... 200 s.

5.- Carnisseria ................. 20 s.

$10.220 \mathrm{~s}$. 
Caudiel:

1.- Peita

$1.650 \mathrm{~s}$

2.- Censals menuts . . . . . . . . . . . . . . $80 \mathrm{~s}$.

3.- Meitat del delme .................... $1.600 \mathrm{s.}$

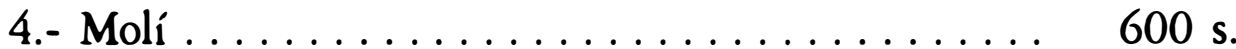

5.- Forn ......................... 150 s.

6.- Carnisseria .................. $5 \mathrm{s.}$

$4.085 \mathrm{~s}$.

Novalitxes:

1.- Peita ............................ $1.250 \mathrm{~s}$

2.- Meitat del delme ................... $600 \mathrm{~s}$.

3.- Molí .......................... 200 s.

4.- Forn i carnisseria ................. $15 \mathrm{~s}$.

$2.065 \mathrm{~s}$.

Suma total del comtat de Xèrica: 42.026 s. (Quadre 21).

La renda de tots aquests llocs és quasi idèntica, amb dos apartats fonamentals: una peita fixa que, en el seu moment, degué ser proporcional a l'extensió del poble -tenim documentat el seu establiment per a Viver, Caudiel i Novalitxes vers 1370 quan foren expulsats els sarraïns i repoblats per cristians-, i un delme que, en el cas de Xèrica i els pobles del seu comtat, és de la meitat del seu valor, i que fluctua prou en proporció a l'anterior en funció de la demografia i els cultius de cadascun dels llocs. Les raons d'aqueixes fluctuacions en les proporcions d'ambdós apartats caldria buscar-les en la circumstància què probablement la peita fou fixada esperant un nivell de població que després no va ser aconseguit $i$, per tant, mentre que en unes viles els veïns augmentaren clarament fent que la part del delme siga més alta -Pina o el Toro-, en unes altres està equilibrada -Caudiel- $i$ en altres és clarament desfavorable als veïns -Viver o Novalitxes-.

La resta de les rendes locals són uns ingressos molt menors dels principals $\mathrm{i}$ comuns monopolis de tot poble: forn i carnisseria, sempre molt més elevat el primer que el segon, $\mathrm{i}$ algun ingrés extraordinari en certs casos: els molins de Viver són arrendats anualment i signifiquen el $20 \%$ dels ingressos, però en canvi a Caudiel sols són un $15 \%$ i a Novalitxes el $10 \%$.

22.- Paterna:

1.- Quint dels blats i herbes, terç de delme, lluïsmes, herbatge i carnatge .................. 12.250 sous 
2.- Delme de les olleries . . . . . . . . . . . . . 9.766/9 s.

3.- Almagram de la terra . . . . . . . . . . . . . . 1.993/4 s.

4.- Cens de les vinyes $\ldots \ldots \ldots \ldots \ldots \ldots \ldots . \ldots 92$ s.

5.- Cens dels horts ................ 40 s.

6.- Sofres de cristians i moros . . . . . . . . . 2.135 s.

7.- Gallines i espatles .................. 105 s.

8.- Alfetras dels moros . . . . . . . . . . . . . 140 s.

9.- Cena de Nadal . . . . . . . . . . . . . . . . . . . 1.000 s.

10.- Carnisseria . . . . . . . . . . . . . . 1.650 s.

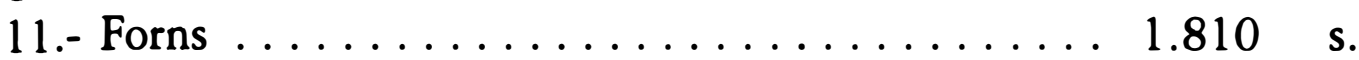

12.- Obrador de la ferreria .............. 15 s.

13.- Molins ................... -

14.- Escrivania de la Cort $\ldots \ldots \ldots \ldots \ldots \ldots \ldots$.

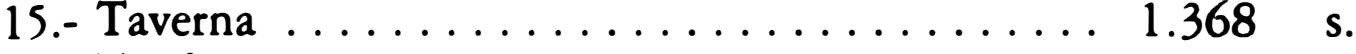

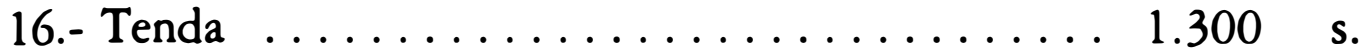

17.- Corredoria ..................... 740 s.

18.- Guardianatge de l'horta . . . . . . . . . . . 270 s.

19.- Sagionia . . . . . . . . . . . . . . . . 140 s.

20.- Banys ..................... 44 s.

21.- Almaxeta .................. 40 s.

22.- Tarquena ................... 40 s.

23.- Barberia ................... 110 s.

35.899 s.

(Quadre 22) ${ }^{27}$.

Paterna i el cas següent de Benaguasil i la Pobla de Vallbona són tres llocs de l'anomentat "Antic Patrimoni» i que procedeixen de la senyoria dels Lluna quasi des dels anys de la conquesta. Es tracta d'un lloc de musulmans i, per tant, mostra una tipologia de les rendes distinta als anteriors, tradicionalment islàmica; en el cas de Paterna, però, amb una peculiaritat total: la presència d'un delme de les olleries -la ceràmica de Paterna- que implica un ingrés absolutament extraordinari tant en la seua existència com en el seu valor: un $27 \%$ del total.

Llevat d'això, Paterna compleix el camí de la normalitat de les aljames sarraïnes valencianes; podem veure com hi ha un altre ingrés fonamental procedent de la partició de les collites - la cinquena part, la qual cosa no l'hem

27. La font sobre les rendes de Paterna és el mateix llibre manuscrit del Batlle General (f. 313 r.-v.), on apareixen també detallades en forma d'ítems totes i cadascuna de les rendes del llistat. 
trobada en cap vila de cristians de les pertanyents al reialenc-, terç de delme i herbatge i carnatge -un $34 \%$ del total-, que encara és superior si hi afegim les altres rendes procedents de les collites: almagram i censos de les vinyes i dels horts: un $42 \%$ del total.

La resta és un molt llarg llistat de rendes, tant monopolis com impostos tradicionals islàmics -sofres, gallines i espatles, alfetràs, almaixeta, tarquena, etc.-, però en què cap no arriba individualment al $6 \%$ del valor total. Agrupant-los un poc, podem veure que els monopolis i regalies, carnisseria, forns, ferreria, taverna, tenda, corredoria, guardianatge de l'horta, sagionia, barberia i els banys, munten aproximadament un destacat $21 \%$-sempre són arrendats, com hem vist que és típic en el cas de les comunitats musulmanes i això els dóna un valor conjunt important-, mentre que les rendes tradicionals islàmiques, sofres, gallines i espatles, alfetràs, cena de Nadal, almaixeta i tarquena no arriben a un $10 \%$.

En resum, més enllà del cas peculiar de les olleries, el qual desfigura la fiscalitat tradicional de les aljames valencianes, podem veure com la tipologia de la renda sobre una aljama en principi rural és molt diferent a la d'una moreria urbana i a la de les viles i pobles, rurals o no, cristians. El pes de les rendes de la terra és molt elevat -en proporció però més encara en valor real-, i el mateix passa amb els monopolis $i$ les regalies $i$ la fiscalitat tradicional islàmica, inexistent a les viles cristianes; en canvi no hi apareix la fiscalitat directa col.lectiva del tipus peita-cena, fent així que el domini de la renda indirecta siga absolut.

\section{3.- Benaguasil:}

1.- Dret dels blats, herbes, horts, figueres, vinyes, gallines, espatles, fusta del riu, herbatge, colmenes, dret del bestiar ............................ $15.200 \mathrm{s.}$

2.- Delme de l'espart ................. $1.650 \mathrm{~s}$.

3.- Almagram ..................... $2.432 \mathrm{s.}$

4.- Cens de la vinya $\mathrm{i}$ un mas ............ $211 \mathrm{~s}$.

5.- Sofres ......................... 768 s.

6.- Molins ...................... $3.400 \mathrm{~s}$.

7.- Molí d'arròs .................. 40 s.

8.- Carnisseria . . . . . . . . . . . . . . . . . . 1.000 s.

9.- Forns ..................... 620 s.

10.- Tenda ...................... $160 \mathrm{s.}$

11.- Taverna ..................... $200 \mathrm{s.}$

12.- Barberia ...................... 313 s.

13.- Bany ....................... $120 \mathrm{s.}$

14.- Almàssera de la cera $\ldots \ldots \ldots \ldots \ldots \ldots . . \ldots$ s. 


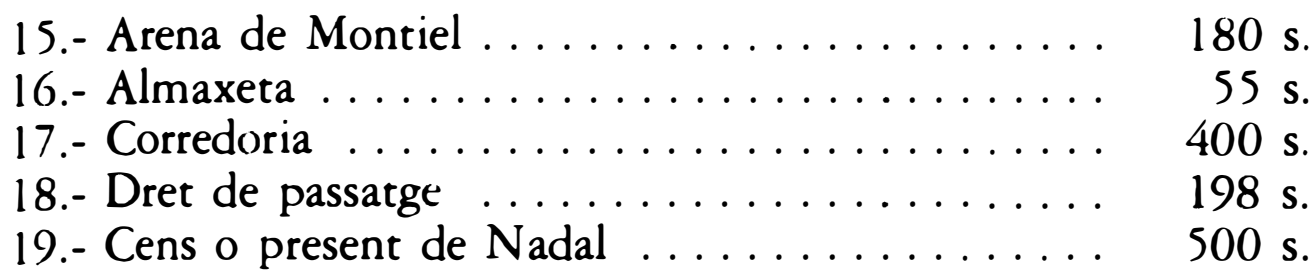

$27.457 \mathrm{~s}$.

(Quadre 23).

La Pobla de Vallbona:

1.- Peita

$4.000 \mathrm{~s}$.

2.- Cens d'una heretat

$393 \mathrm{~s}$.

3.- Escrivania de la Cort . . . . . . . . . . . . . $100 \mathrm{~s}$

4.- Terç de delme . . . . . . . . . . . . . . . $2.000 \mathrm{s.}$

5.- Carnisseria . . . . . . . . . . . . . . . . 900 s.

$7.393 \mathrm{~s}$.

(Quadre 24).

Suma rendes senyoria Benaguasil i la Pobla de Vallbona: $34.850 \mathrm{~s}^{28}$.

Cal tenir en compte que ambdós llocs pertanyen a la mateixa unitat senyorial o terme, d'on Benaguasil és la vila més antiga i on continuen vivint els musulmans, mentre que la Pobla de Vallbona és una fundació cristiana de la darreria del segle XIII i on ara hi vivien sols cristians.

Aquest cas és un molt bon exemple de les grans diferències que hi havia en la tipologia, composició $i$ valor de la renda feudal entre pobles de musulmans $i$ de cristians en la València medieval. La renda feudal de la Pobla consta de molt pocs apartats, basats en una imposició directa i fixa -la peita-, que munta ella a soles un $54 \%$ dels ingressos totals; es veu complementada per un segon aspecte bàsic, el terç de delme, el qual en aquest cas ve a significar un poc més de la quarta part del total -un $27 \%$-. La resta són tres ingressos de menor valor llevat de la carnisseria, arrendada anualment, i que comporta un $12 \%$ de les rendes cristianes.

En canvi, les rendes fiscals sobre l'aljama de Benaguasil són del mateix ventall $\mathrm{i}$ elevat volum que hem vist abans per a Paterna; fins i tot diriem que

2* La font és també el llibre inventari del Batlle General (f. 315 r-v.), on hi consten enumerades també en forma d'ítems diferenciats; hem mantingut aqueixa classificació, sols separant en dues parts les rendes de Benaguasil i les de la Pobla en raó de ser poble de moros i cristians, respectivament. 
aquesta comunitat és un millor model d'aljama rural en quant que la detracció de la renda no té un apartat deformador com ho era la renda de les olleries. A Benaguasil, per una banda ens trobem un llarg llistat de rendes agràries que graven tot el món rural i els més diversos monopolis -cosa inexistent a les comunitats cristianes- , i per una altra ens trobem que no estan mai donats a cens sinó que sempre són arrendats anualment de manera que els ingressos reals per al beneficiari -ací la monarquia- són molt més elevats.

El component fonamental són les rendes agràries, «el dret dels blats, herbes, horts, figueres, vinyes, herbatge, colmenes i bestiar" -sembla que fan una partició de la cinquena-, als quals afegeix en l'arrendament $i$ valor total els apartats de «les gallines, espatles i fusta del riu»; si tot això ja significa un $55 \%$ del total, quan li afegim les altres rendes de tipus agrari, delme de l'espart, almagram i cens de la vinya, el seu volum ja arriba al $71 \%$. La resta de la renda anual procedeix en bona mida dels diversos i abundants monopolis, tant de comercialització com de producció -forns, tenda, taverna, barberia, bany, almàssera de la cera, arena del jaciment de Montiel, almaxeta, corredoria i dret del passatge, als quals cal afegir per separat en funció del seu més elevat valor els molins -un d'aqueixos d'arròs- $i$ les carnisseries; si cadascun no solia tenir tant de valor per separat -llevat dels suara esmentats-, el conjunt pujava un poc més del $26 \%$ del total, proporció molt més alta que a la majoria de les viles cristianes. La resta era formada per dos ingressos de tipus més personal com ara les sofres -2 ' $8 \%$ - $i$ el pagament col.lectiu o present de Nadal -un 1'8\% més-.

En resum, resta palesa la gran diferència d'imposicions entre ambdues comunitats, l'elevat valor de les rendes pagades pels sarraïns i el que resten sotmesos a una varietat molt més àmplia i aclaparadora de formes d'extracció de renda per quasi totes les activitats econòmiques i productives possibles.

Hem localitzat una notícia de l'any 1418 que ens aporta un llistat de focs d'aquestes dues viles de cara a afrontar el pagament d'un censal juntament amb la resta de llocs de l'anomenat "Antic Patrimoni» ${ }^{29}$; en aqueix llistat Benaguasil apareix amb 201 focs i la Pobla de Vallbona amb 165; més enllà de la veracitat demogràfica de les dades fiscals, la proporció de veïns entre una $i$ altra i la "pressió fiscal teòrica» sobre cada foc palesa de totes totes la diferent realitat exactiva sobre una i altra comunitat: mentre entre els cristians de la Pobla, la mitjana de pressió fiscal surt a $45 \mathrm{~s}$. per foc aproximadament, els seus conveïns sarraïns de Benaguasil devien fer front a una mitjana de $136 \mathrm{~s}$./foc $\mathrm{i}$ any. Sens dubte caldrà fer algunes correccions en raó d'alguns monopolis que

${ }^{29}$ ARV, Pergamins, caixa 16, n.20. Citat i publicat parcialment per J.Nicolau (1990), p. 60 . 
probablement eren de comunals -molins, etc.-, però no deixa de ser tota una mostra de per on anaven els camins de l'exacció fiscal.

\section{4.- Vall d'Uixò, Eslida, Vall d'Almonesir i Castro:}

Finalment, el llibre inventari del Batlle General de 1414 hi afegeix altres quatre aljames musulmanes incloses en l'esmentat "Antic Patrimoni» $i$, per tant, formant part de la senyoria particular de la monarquia al País Valencià. Es tracta de la Vall d'Uixò, la Serra d'Eslida, la Vall d'Almonesir i els castells de Castro i Fondeguilla; les hem deixades al final no per altra raó que perquè no detallen la composició i tipologia de les rendes concretes que pagaven. La informació del Batlle General es limita a indicar que les rendes d'aqueixos indrets eren arrendades anualment o per dos o tres anys a les mateixes aljames, d'una manera global, i es limita a anotar al seu llibre el valor estimat com a més comú, quantitat que especifiquem a continuació. L'única informació complementària sobre aquestes aljames és el llistat individualitzat de tots els pagaments, càrrecs i pensions que devien assumir anualment aqueixos ingressos, de manera que, malgrat tractar-se de quantitats molt elevades en algún dels casos -Vall d'Uixó o Eslida especialment-, en la pràctica l'ingrés real en el compte del Batlle General i de la monarquia podia considerar-se pràcticament nul. Amb tot, recordem una vegada més que no és l'objectiu d'aquest treball analitzar la hisenda reial al País Valencià en el seu conjunt sinó la composició del Patrimoni Reial i la tipologia i els valors de les diverses formes d'exacció que graven aqueix patrimoni en base a la fiscalitat reial ordinària.

Les dades de la renda en aqueixes quatre aljames són les següents:

La Vall d'Uixò:

- Rendes globals sense detall . . . . . . . . . . . . . 21.500 s.

Serra d'Eslida:

- Rendes globals sense detall ................... 23.500 s.

La Vall d'Almonesir:

- Rendes globals sense detall .................. 14.550 s.

Castro i Fondeguilla:

- Rendes globals sense detall . . . . . . . . . . . . . . . . . 3.300 s. 


\section{El PATRIMONI Reial al País VALenCià A INICIS DEL SEGLE XV}

Hem vist en aquest exhaustiu i de vegades picallós panorama quines eren les viles $\mathrm{i}$ els llocs que conformaven la geografia del patrimoni reial al País Valencià a inicis del segle XV. El detall que hem fet de la composició i dels valors de les rendes obtingudes per la monarquia en totes i cadascuna d'aqueixes poblacions ens ha donat les pistes sobre quina era la fiscalitat ordinària de la corona en aqueix moment, quins eren els mecanismes d'exacció més importants i quins béns - monopolis i regalies- conformaven els drets que n'havien conservat en els pobles.

Abans de fer el balanç de les característiques generals de la renda de la monarquia en base al seu patrimoni reial, podem veure en dos quadres la importància relativa i proporcional de les rendes obtingudes des de cadascuna de les viles valencianes que li pertanyen a inicis del segle XV; la seua geografia ja l'hem comentada al principi del treball i l'hem representada al mapa annex; al quadre 25 podem veure el tant per cent dels ingressos que eren obtinguts a les viles de reialenc: pot parlar-se d'una jerarquia encapçalada per Xàtiva -quasi una quarta part de les rendes de les viles eren pagades allí, seguida de prop per Morella i més lluny per Morvedre i Alzira, i fins i tot Castelló de la Plana; la resta de batllies reials impliquen uns nivells d'extracció de renda per part de la monarquia molt més baixos en valors totals, ja que les cinc esmentades arriben a un $75 \%$ dels impostos reials ordinaris del regne valencià, exclosa la capital. És clar que aquests valors resten molt minvats quan els comparem amb el valor de la renda obtingut a la ciutat de València; sols aquesta batllia recapta uns 277.000 s. a l'any, mentre totes les batllies del regne juntes sumen 221.000 sous; els 55.000 sous a l'any de Xàtiva no són ni el $20 \%$ de les rendes obtingudes per la corona a la capital.

Un quadre semblant hem fet amb les rendes recaptades a les viles anomenades de l'Antic Patrimoni; tal com pot veure's al quadre 26, el componen 16 viles i llocs o aljames, amb un repartiment entre aqueixes més igualat que entre les batllies reials estrictes; hi ha un primer grup de nuclis -Paterna, Benaguasil i la Pobla de Vallbona, i el comtat de Xèrica- que es troben entre el 15 i el $20 \%$ del total, però llevat de l'aljama de Castro no hi ha tans grans diferències entre totes plegades.

El total de les rendes de l'Antic Patrimoni també és inferior al valor de les obtingudes a la ciutat de València -205.000 sous davant els esmentats 277.000 s. - , i molt a prop del que aconseguia la monarquia de totes les batllies reials del regne en aqueixa època; volem assenyalar, però, que com a casos individuals de pobles d'aqueix Antic Patrimoni representen una extracció de renda superior a la gran majoria de les viles de reialenc; llevat de Xàtiva i la seua moreria, i de Morella, llocs com el comtat de Xèrica amb 42.000 s./any i 
Paterna amb 35.000 s. o Benaguasil-La Pobla amb 34.000 s., representen quantitats superiors a les de qualsevol altra vila reial, superiors a les rendes de Morvedre o Alzira, i el doble de les rendes de Castelló de la Plana; i així podríem continuar amb les comparacions. ( $\mathrm{Al}$ quadre 31 poden veure's els valors totals de les rendes de cadascuna de les poblacions).

Anem ara a fer un balanç de quines serien les característiques i tipologia del conjunt de la renda ordinària de la monarquia al País Valencià a inicis del segle $\mathrm{XV}$, fent una distinció primer entre les viles reials estrictament d'aquelles que conformen l'anomenat Antic Patrimoni -quadres 27 i 28 respectivament-, per acabar amb les proporcions en el conjunt del regne valencià -quadre 29-.

Tal com ho podem veure al quadre 27, la composició global de la renda ordinària de la monarquia en el patrimoni reial del País Valencià a inicis del segle $\mathrm{XV}$, té un model bàsic a totes les viles reials d'aqueix moment -exclosa la batllia de València- $\mathrm{i}$ que, amb variants locals, $s$ 'hi troba centrat en el terç de delme -0 una altra porció segons viles-, el qual representa poc més del $40 \%$ de la fiscalitat total reial; es veu complementat per una fiscalitat directa, de caràcter fix ara, que, amb els noms de peita i cena, sumen un altre $30 \%$ de les imposicions totals ordinàries. Amb totes dues hom supera amb escreix els dos terços del total, $\mathrm{i}$ deixa la resta de rendes a nivells clarament marginals, potser amb l'excepció dels tradicionals monopolis -amb la seua gamma de molins, forns, carnisseries, cases, terres, etc.-, els quals munten sobre un $13 \%$; això és degut bàsicament al fet que a la majoria de viles s'hi troben establerts emfitèuticament -als llocs on són arrendats, algun o alguns, el seu valor creix moltíssim: a Morvedre per exemple són un terç de les rendes-. Si més no, els monopolis vénen a representar en la majoria de casos el domini eminent sobre uns centenars de molins, forns, carnisseries, cases o parcel.les de terra disperses pel país, però no té majors repercussions; després de rebre la renda anual, la monarquia no exerceix cap dret efectiu sobre tots aqueixos -no hem trobat constància d'això mai-, per la qual cosa podem considerar encertadament que han restat convertits els dits monopolis en una simple renda econòmica anual.

Aquesta tipologia i els valors de les rendes reials ordinàries mostren per tant els trets d'un model molt poc flexible, en el que entre un $40 \mathrm{i}$ un $50 \%$ de la renda és fixa -peita, cena i bona part dels monopolis establerts a cens emfitèutic-, mentre que un altre $40 \%$ pot fluctuar en base a les millors o pitjors collites anuals però no té possibilitats de creixement a voluntat reial sinó sols a partir de l'augment de les collites, bàsicament del forment que és el component dominant aclaparadorament de les particions del delme; també ens adonem que llevat d'algun poble concret -Morella amb el safrà, Xàtiva amb la morera-, o els cultius són molt poc diversificats o bé el gravamen del delme no arriba a nous productes $i$ resta ancorat en l'agricultura més tradicional del cereal i del vi. 
El $15 \%$ restant de les rendes reials estava format per un grapat ampli de menudes rendes quant al seu valor proporcional: des de les relacionades amb sistemes de monopoli, com ara l'almodí, la gabella de la sal o l'herbatge, fins els lluissmes procedents de les vendes dels béns emfitèutics del patrimoni reial, passant pel morabatí, el qual hem vist comptabilitzat en diversos llocs de forma anual a raó d'un sou per foc. Fem especial esment en el fet que les rendes del comerç gestionades pels batlles locals són molt baixes car són en bona mesura antics sistemes fiscals com la lleuda i el passatge o les coses vedades, i resten al marge d'aquesta gestió les rendes de les generalitats o les sises municipals que semblen ser al segle XV les realment importants.

També ressalta el fet que les estrictes rendes de la justícia i el poder jurisdiccional, les procedents de les multes i calònies dels oficials locals, representen una quantitat mínima o nul.la perquè en la seua major part van dedicades a pagar els salaris corresponents, $\mathrm{i}$ això és una constant per enlloc. Sols sembla dur una dinàmica diferent el cas de la ciutat de València, on el Batlle General del Regne centralitza part del sistema judicial criminal i del mer imperi de tot el regne, de manera que allí hi ha uns ingressos ja significatius -el $30 \%-$.

A les anomenades viles de l'antic Patrimoni i que són la senyoria «particular» de la corona en aquesta època, la composició de la renda -tal com pot veure's al quadre 28-, presenta algunes modificacions dins d'uns trets generals força semblants; la gràfica palesa una major claredat, amb un element molt dominant, el delme, complementat per uns monopolis molt més alts $\mathrm{i}$ una peita en tercer lloc.

La part de delme -que inclou les rendes agràries de les aljames musulmanes, i això en deu ser la raó fonamental-, és més elevat ara, quasi un $45 \%$, mentre que la peita-cena baixen $\mathrm{i}$ es queden en un $20 \%$. El guany bàsicament l'arrepleguen els monopolis, els quals quasi arriben a un $30 \%$ net si hi incloem altres rendes relacionades com ara l'herbatge, els lluïsmes i l'almodí; les rendes de la justícia i del comerç també són insignificants. Les raons $\mathrm{d}$ 'aqueixes diferències amb les batllies reials cal buscar-les en la diferent composició d'un i altre grup: ací s'hi inclouen diverses aljames sarraïnes, les quals són les que, amb la seua diferent composició de la renda, alteren els valors proporcionals.

Això ens fa constatar com la composició de la renda és diferent entre viles cristianes i musulmanes, tal com ja ho hem explicat, i que hi ha total similitud entre viles reials i viles poblades per cristians de la senyoria de l'antic Patrimoni: la composició de la renda a Sogorb, Xèrica i el seu comtat, o Llíria, és clarament semblant a la de la resta de viles de reialenc. Són els llocs de sarraïns els que no tenen impostos directes ordinaris -peita-cena-, per la qual cosa l'ingrés de les rendes agràries -no limitades a la part de delme sinó molt més variades, abundants i gravoses $-\mathrm{i}$ dels monopolis -sempre arrendats i mai no 
establerts emfitèuticament-, aporten uns ingressos molt més elevats i potser més fluctuants, però també molt més a prop de tota la producció, guanys i consum dels pobladors del terme. No cal dubtar així que una vila de sarraïns és molt més rendible que una de cristians, i pensem que ací hi ha una pista clara per entendre per què ja des del segle XIV quasi totes les aljames són senyorials -i no tant arguments discutibles sobre la protecció religiosa, etc. -. ${ }^{30}$

Les diferències més clares, però, venen amb la ciutat i batllia de València, la qual careix del pagament de la peita des de poc després de la meitat del segle XIV -el mateix cas que amb el morabatí i també l'herbatge, aquest des d'època del rei Martí-, i a més presenta un quadre trastocat respecte a la resta de viles reials (Vegeu quadre 1). El component dominant ací són les rendes comercials: taula del pes reial, coses vedades, lleuda de Tortosa, dret dels italians i dels jueus de Barbaria, tots els quals arriben ben bé a un $44 \%$; el segon component dels ingressos és tota la varietat de multes, calònies, redempcions i perdons convertits en multa, drets fiscals sobre l'eixida de musulmans del regne, permisos d'acaptar els musulmans esclaus, etc.; tot junt arriba a un $30 \%$ l'any 1415 , malgrat que pot fluctuar clarament d'un any a l'altre pel seu caràcter totalment irregular.

Tot plegat, aquestes dues vies fiscals fan que la renda de la batllia de València redueixca els ingressos del terç de delme -amb tota la seua varietat de cereals, vi, hortalissa i carnatge- a un $7 \%$, fins i tot inferior als importants ingressos anuals del monopoli de la sal i del peix de l'Albufera de València -un $9 \%$-, els quals no hem pogut destriar perquè des d'inicis del segle XIV apareixen sempre arrendats conjuntament ${ }^{31}$.

Els tradicionals monopolis, en el cas de la Ciutat devien consistir en un cert nombre destacat de cases, forns, obradors, etc., que no hem pogut calcular exactament atès que una part dels seus censos eren abonats directament a institucions religioses; amb tot, no devien ser sinó sols una part de tots els elements d'aquesta mena existents allà, car bona part n'eren propietat alodial de veïns per donació dels diversos monarques amb el pas del temps. Quantitativament parlant, representen un ingrés molt baix respecte a les rendes ordinàries de la Ciutat - un 2'7\%-, a la qual cosa caldria afegir el valor dels llü̈smes i l'almodí; és probable, però, que estiguen subvalorats en la seua presència real perquè, des del regnat de Pere el Cerimoniòs, tots els ingressos dels monopolis de la ciutat de València foren donats i pagats anualment als rectors de la capella del Palau Reial de València, per la qual cosa sols les rendes dels novament (1985).

3n Algunes consideracions sobre això en E.Guinot, 1992 b.

${ }^{31}$ Les dades i notícies sobre el quint del peix i l'Albufera les hem tretes de R.Muñoz 
establerts entre la dècada de 1360 i el moment de l'estudi -1415-, són inclosos en aquestes quantitats. Sí que cal subratllar que, tal com és força general a les viles reials, tots els monopolis de la ciutat de València són establerts emfitèuticament i no hi ha cap arrendat, amb la consegúent pérdua d'ingressos que implicava aquest fet.

També cal aclarir que no tots els ingressos que apareixen sota l'epígraf batllia de València corresponen exclussivament a la ciutat; part de les rendes comercials són pagades a aquesta però no per productes comprats o venuts al seu mercat local sinó que circulen dins o fora del regne; el mateix passa amb les rendes de la justícia, les quals, en bona mesura, corresponen a multes, etc., imposades a persones de tot el regne però sotmeses a la jurisdicció del Batlle General del Regne. És per aquest caràcter mixt entre rendes locals de la ciutat $\mathrm{i}$ del regne que hem inclòs en la seua comptabilitat els ingressos de la cena i del morabatí de diversos pobles valencians, els quals són recaptats per aquest funcionari en viles que no eren de reialenc.

Aquestes matitzacions són les que en part poden quedar compensades amb el quadre final 29, on apareixen les proporcions de les rendes totals ordinàries de la monarquia al País Valencià a inicis del segle XV. Ací pot veure's que han estat limitats els components més forts dels quadres anteriors $\mathrm{i}$ que hi ha menor distància entre unes $i$ altres rendes bàsiques: un terç de delme que val vora una quarta part de les rendes; uns ingressos de la fiscalitat comercial que són una altra cinquena part; i tres blocs complementaris entre el 12 i el $15 \%$ : la fiscalitat directa i fixa del grup peita-cena, els monopolis que aporten censos a la corona $\mathrm{i}$ les rendes de la justícia $\mathrm{i}$ els seus annexes, especialment la jurisdicció sobre els sarraïns.

Rendes fixes serien pràcticament tan sols el bloc peita-cena i bona part dels monopolis, la qual cosa vol dir un $25 \%$ aproximadament; la major part de la hisenda reial $-75 \%$ - està sotmesa a la recaptació sobre l'activitat econòmica dels valencians, siga agro-pecuària, siga comercial, mentre resta aqueix apartat de la jurisdicció, molt més aleatori que els altres, i que palesa una certa major importància del què hem considerat tradicionalment.

Un darrer quadre, però, ens situa crec que de manera molt més ajustada la realitat d'aquestes rendes ordinàries de la monarquia $\mathrm{i}$ el seu pes relatiu. El mateix any 1415 -sobre el qual hem centrat la majoria de dades i rendes amb cronologia i valors exactes-, el Batlle General del Regne de València va recaptar dues tatxes extraordinàries, l'una arran de la necessitat d'armar un estol per anar a la guerra a l'illa de Sardenya, i l'altra en raó de les noces del seu fill i hereu Alfons, futur Alfons el Magnànim; aproximadament, cadascuna va tenir un valor de 110.000 sous repartits entre les viles valencianes, de reialenc o no, en base als seus focs fiscals; a més a més, el mateix any el rei Ferran va fer arribar una nau des de Sicília farcida de forment, el qual va ser venut a l'almodí de València i també a la vila de Requena, a Castella, on hi havia hagut sequera 
aqueix any; també acabà venent a trossos la susdita nau, desfeta al grau de la mar de la ciutat de València -només cal subratllar que els ingressos en la hisenda reial d'aquestes dues darreres vendes representaren més diners (67.482 s.) que qualsevol de les rendes ordinàries de les dues majors viles del regne, Xàtiva o Morella-. Finalment, i dins les rendes irregulars que anava anotant el Batlle General del Regne a la seua comptabilitat, cal destacar uns ingressos del voltant dels $50.000 \mathrm{~s}$. en aqueix any que corresponen a demandes i compensacions extraordinàries exigides pel monarca a diverses viles valencianes, cristianes i sarraïnes; per eixemple, bona part d'aqueixa quantitat procedeix de les peticions d'hòmens d'armes i la compensació en diners que acceptava el rei a canvi què no foren mobilitzats veïns de la vila en qüestió -encara en aquest any Ferran I estava amortitzant mobilitzacions d'hòmens d'armes per a la guerra contra el Comte d'Urgell-.

Així doncs, el quadre d'ingressos totals de la monarquia al cas del Regne de València a inicis del segle XV és el següent:

Ciutat de València . . . . . . . . . . . . . . . . . 277.718 s.

Viles reials . . . . . . . . . . . . . . . . . . 221.745 s.

Antic Patrimoni . . . . . . . . . . . . . . . . . . . 205.069 s.

$704.532 \mathrm{~s}$.

Subvenció Sardenya . . . . . . . . . . . . . . . . $110.043 \mathrm{s.}$

Noces infant Alfons . . . . . . . . . . . . . . . 110.482 s.

Vendes blat i nau ................. $67.482 \mathrm{~s}$.

Demandes extres a viles reials ............ $50.000 \mathrm{~s}$.

$338.007 \mathrm{~s}$.

Les quantitats d'aquest segon bloc són molt irregulars i no convé prendreles d'una manera absoluta perquè, d'any en any, varien força; no deixa, però, de ser simptomàtic que en els anys del regnat de Ferran I apareguen de anualment aquestes demandes extraordinàries i directes sota un o altre títol: en 1413 hi ha dues tatxes generals: $146.749 \mathrm{~s}$. pel coronatge del rei, i $84.828 \mathrm{~s}$. pel novell regiment, a més de la venda del forment d'una nau procedent de Sevilla; a més a més, aquesta venda va rebre l'ajuda corresponent del consell municipal de la ciutat: en total 210.461 sous més d'ingressos irregulars. En 1414, en menor mesura, hi ha una nova tatxa general: $74.814 \mathrm{~s}$. recaptats per tot el regne en raó del coronatge de la reina.

El resultat de tot això és francament desestabilitzador per a la valoració de la hisenda ordinària reial; tal com pot veure's al quadre anterior, on hem detallat les rendes de l'any 1415 , que les rendes ordinàries de la monarquia al País Valencià es vegen augmentades en un $50 \%$ per l'aleatorietat de les tatxes 
directes sobre la població amb una o altra excusa $-i$ tots els anys n'hi ha alguna-, o que el rei puga ingressar quasi tants diners per la venda de forment en 1413 com per totes les rendes ordinàries de totes les viles reials del Regne (210.000 s. front a 221.000) fa que pensar sobre la real importància del Patrimoni reial en aqueixa època.

Cal recordar que aquesta fiscalitat ordinària de la monarquia no era l'única existent sinó que es veïa complementada per l'anomenada fiscalitat del regne, això és, la controlada per la Generalitat per a recaptar els subsidis aprovats en Corts. La seus destinació final també era la monarquia, però la seua organització i recaptació restava al marge de la hisenda ordinària, raó per la qual és general en els estudis sobre la hisenda medieval estudiar-ho de forma separada. En el cas valencià, la recaptació de la Generalitat disposava de dues vies: la de l'impost directe amb l'anomenat "compartiment» -una tatxa a repartir entre els veïns dels pobles adscrits a cadascun dels tres braços, reial, nobiliari i eclesiàstic, en base a la demografia respectiva, i la via indirecta dels impostos comercials de les Generalitats; durant el regnat de Ferran I no hi hagué "compartiment", sinó tan sols la recaptació dels impostos comercials que varen muntar a 385.000 sous valencians en $1413 \mathrm{i}$ $1414,435.000$ s. en $1415,427.000$ s. en 1416 i 479.000 s. en 1417.

Aquestes quantitats, com podem veure, són molt elevades i superiors per molt a allò que era recaptat mitjançant els ingressos ordinaris teòrics en totes les batllies reials valencianes, en conjunt, o al valor mateix de la batllia de la ciutat de València.

Una valoració final dóna encara més força a aquesta composició dels ingressos de la hisenda reial: amb diferències locals, bona part de les rendes ordinàries es trobaven alienades de diversa manera: consignades en pensions anuals a diverses persones nobles $\mathrm{i} / \mathrm{o}$ institucions eclesiàstiques, dedicades al pagament de pensions de censals carregats anteriorment per la corona, fins i tot embargades de manera absoluta com passà amb les rendes de Morella, Castelló, Alzira i Morvedre a finals del regnat del rei Martí, les quals viles es trobaven gestionades per la Diputació de la Generalitat arran d'un préstec fet al rei. No hem fet un estudi detallat de les consignacions de quantitats exactes malgrat que podria fer-se una bona aproximació reconstruint les informacions; no és aquest l'objectiu del treball, tal com ja ho hem explicat abans, però és fonamental tenir en compte aquesta realitat perquè informacions del mateix Batlle General en fer la seua enquesta mostren, per eixemple, com dels 21.500 sous recaptats a la Vall d'Uixó, 21.000 van directament a diverses mans, i el 175-306.

${ }^{12}$ Les dades i l'estudi del tema en R.Muñoz (1987), especialment capítol III-2, pp. 
mateix passa amb els 23.000 sous anuals de la Serra d'Eslida, i així podríem seguir per enlloc.

En resum, aquesta aproximació a l'estudi de la hisenda reial al País Valencià a inicis del segle XV ens mostra una realitat del Patrimoni Reial prou debilitat en els seus components més tradicionals, amb unes viles de reialenc que basen la seua fiscalitat ordinària en la quantitat fixa de la peita-cena $i$ les exaccions del delme -terç o una altra proporció-, i un grapat de monopolis molt dispersos i que sols ocasionalment es mantenen en arrendament perquè la gran majoria paguen uns censos emfitèutics molt baixos i devaluats. La capitalitat de la ciutat de València també es fa evident, així com el valor important que tenen les rendes comercials $i$ jurisdiccionals en aquest cas, però volem acabar subratllant dos aspectes; un, de més concret, i és que moltes viles "de senyoria», on es paguen rendes agràries o els monopolis són arrendats, així com quasi qualsevol aljama de sarraïns, són proporcionalment molt més rendibles que les batllies reials, fins i tot per a la mateixa monarquia i no sols per a la noblesa; cal pensar que si la monarquia no es queda amb prelació aqueixes viles no és perquè siga «dèbil» sinó perquè subministrar i distribuir rendes a la noblesa és també el seu paper en la jerarquia feudal.

La segona observació és més de tipus macroeconòmic: les xifres que hem anat aportant són de tipus aproximat, referides de vegades a anys concrets $i$, per tant, sotmeses a les naturals fluctuacions, però pensem que marquen tendències a tenir en compte. Les rendes ordinàries de la monarquia són baixes, però és que a més no arriben a les seues mans en bona part; a inicis del segle XV al rei no li deu arribar més d'un $25 \%$ de les rendes de les batllies reials, llevat de la ciutat de València; tampoc no hem fet el càlcul de l'ingrés real de les viles de l'Antic Patrimoni però, pel que hem vist sospitem que encara siga inferior aqueixa quantitat ja que molt d'aquest es troba prèviament consignat a institucions eclesiàstiques, nobles i creditors de tot color i pèl. A la monarquia, així el que li resta són bàsicament les rendes de la ciutat de València, també consignades en part $i$, per tant, els ingressos extraordinaris que aconsegueix mitjançant el Batlle General, -de la venda de forment a les demandes d'hòmens $d$ 'armes bescanviades en sumes de diners-. Amb aquest panorama la fiscalitat extraordinària de "Coronatges», "campanyes de Sardenya», etc. comença a tenir un valor molt més gran en tants per cent, ja que sembla ser la part que més directament arriba al monarca via Batlle General; el mateix paper podriem atribuir també als pagaments de les Corts via la Diputació de la Generalitat, fets que així palesen les transformacions que devien estar produint-se en aqueix vell concepte de Patrimoni Reial a inicis del segle XV. 


\section{BIBLIOGRAFIA}

ARAGÓ (A.M.)- CONDE (R.), Evolució de les rendes del conflent sota Pere el Cerimoniós (1345-1386), "Conflent, Vallespir et Montagnes catalanes». («Actes du LI Congrès de la Fédération historique du Languedoc Méditerranéen et du Roussillon»), Montpellier, 1980, pp. 111-121.

BISSON (TH.N.), Las finanzas del joven Jaime I (1213-1228), «X Congreso de Historia de la Corona de Aragón», Saragossa, 1980, pp. 161-208.

BISSON (TH.N.), Fiscal Accounts of Catalonia under the early Count-Kings (1151-1213), Berkeley-Los Angeles-London, 1984.

BOfarull (M.de), Rentas de la antigua Corona de Aragón, Colección de documentos inéditos del archivo de la Corona de Aragón CODOIN, Barcelona, 1871.

BRANCHAT (V.), Tratado de los derechos y regalías que corresponden al Real Patrimonio del Reyno de Valencia y de la jurisdicción del Intendente como subrogado en lugar del antiguo Bayle General, València, 1784-1786, 3 vols., Ed.de José $\mathrm{i}$ Tomàs de Orga.

CABANES PECOURT (M.D.), Desarrollo económico de las bailías de Alpuente y Caltielfabib a fines del siglo XV (1486-1499), "Cuadernos de Historia. Anexos Hispania», 5 (1975), pp. 215-240.

CABESTANY (J.F.) - SOBREQUÉS (J.), Elx i Crevillent, baronia de Barcelona (1391-1473). Notes i documents per al seu estudi, «Ier Congrés d'història del País Valencià», València, 1971, 2, pp. 625-638.

CATeura (P.), Política y finanzas del Reino de Mallorca bajo Pedro IV de Aragón, Palma de Mallorca, 1982.

CRUSELlES GÓMEZ (E.), El Maestre Racional de Valencia. Función política y desarrollo administrativo.del oficio público en el siglo XV, València, Alfons el Magnànim, 1989.

FERRER I MALLOL (M.T.), El patrimoni reial $i$ la recuperació dels senyorius jurisdiccionals en els estat catalano-aragonesos a la fi del segle XIV, "Anuario de Estudios Medievales», VII (1970-1971), pp.351-391.

FERRER I MALLOL (M.T.), Les aljames sarraines de la Governació d'Oriola en el segle XIV, Barcelona, CSIC, 1988, capítol 4 més en concret.

GONZÁLEZ HURTEBISE (E.), Libros de tesorería de la casa Real de Aragón, l. reinado de Jaime II, Barcelona, 1911. 
GUILLERÉ (Ch.) Les finances royales à la fin du règne d'Alfonso IV el Benigne (1335-1336), «Mélanges de la Casa de Velázquez», XVIII-1 1 (1982), pp. 3360.

GUILLERÉ (Ch.), Les finances publiques en Roussillon-Cerdagne au milieu du XIVe siècle. Comptes des procureurs royaux pour l'année 1345-1346, "Annales du Midi", XCVI (1984).

GUILLERÉ (Ch.), Les finances de la corona d'Aragó, "L'Avenç", 139 (1990), pp. 54-58.

GUINOT (E.), La gestió dels llocs de reialenc: les rendes de la batllia de Corbera (1432-1465), «Economia agrària i història local. I Assemblea d'Història de la Ribera» (1981), València, Ed.Alfons el Magnànim, pp. 291-306.

GUINOT (E.), Senyoriu $i$ reialenc al Pais Valencià, a les darreries de l'època medieval, "Congrés Internacional 'Lluís de Santángel i el seu temps'", València, 1992, Ajuntament de València, pp. 185-204.

GUINOT (E.), Los mudéjares de la Valencia medieval: renta y señorio, "Areas». Revista de Ciencias Sociales, Universidad de Murcia (en premsa).

KÜCHLER (W.), Die Finanzen der Krone von Aragon wäbrend des 15.Jabrunderts (Alfons V.und Joan II.), Münster, 1985.

LEDESMA RUBIO (M.L.), El Patrimonio real de Aragón a fines del siglo XIV: los dominios y rentas de Violante de Bar, "Aragón en la Edad Media», II, Zaragoza, 1979, pp. 135-169.

MONTAGUT (T. de), L'administració financera a la Corona d'Aragó, segles XIII-XV, Historia de la Hacienda española. Homenaje al profesor L. García de Valdeavellano, Madrid, 1982, pp. 483-504.

MONTAGUT (T. de), L'administració financera a la Corona d'Aragó, segles XIII-XV, «L'Avenç», 139 (1990), pp. 34 i 51- 53.

MUÑOZ (R.), El quint del peix de l'Albufera $i$ el ters delme de la mar, "Afers», 1 (1985), pp.43-59.

MUÑOZ (R.), Origenes de la Generalidad Valenciana, València, Generalitat Valenciana, 1987.

Nicolau Bauza (J.), Pàgines de la bistòria de Benaguasil, Ajuntament de Benaguasil, 1990, 331 pp.

SÁNCHEZ MARTÍNEZ (M.), La fiscalitat reial a Catalunya en el segle XIV, "L'Avenç», 139 (1990), pp. 28-33.

SANMARTí ROSET (M.), El patrimoni reial a Catalunya durant els anys 12861289, «XI Congreso de Historia de la Corona de Aragón», 4, Palermo, 1982, pp. 213-220.

SARASA SÁNCHEZ (E.), La Hacienda real de Aragón en el siglo XV, Historia de la Hacienda Española. Homenaje al profesor L.García de Valdeavellano, 1982, pp. 823-844.

SARASA SÁNCHEZ (E.), Aragón en el reinado de Fernando I (1412-1416). 
Gobierno y administración. Constitución política. Hacienda real, Zaragoza, Institución Fernando el Católico, 1986, pp.87-146.

VendRell Gallostra (F.), Rentas reales de Aragón de la época de Fernando I (1412-1416), CoDOIN, XLVII, Barcelona, 1977. VICIANO (P.), La senyoria reial al País Valencià. Rendes i gestors de la batllia de Castelló (1366-1500) (en premsa).

QUADRE 30.

Rendes Ciutat Valèn. Batllies R.V. Antic Patr. Total.

\begin{tabular}{|c|c|c|c|c|}
\hline \multirow{10}{*}{$\begin{array}{l}\text { Peita } \\
\text { Cena } \\
\text { Delme } \\
\text { Monopolis } \\
\text { Morabatí } \\
\text { Jurisdicció } \\
\text { Herbatge } \\
\text { Comercials } \\
\text { Lluïsmes } \\
\text { Sal } \\
\text { Almodí } \\
\text { Altres }\end{array}$} & $(\overline{2.400 \text { s. })}$ & $\begin{array}{r}60.600 \mathrm{~s} \\
6.682 \mathrm{~s}\end{array}$ & $\begin{array}{r}27.781 \mathrm{~s} \\
400 \mathrm{~s}\end{array}$ & $\begin{aligned} 88.741 \mathrm{~s} \\
7.082 \mathrm{~s} .\end{aligned}$ \\
\hline & $20.196 \mathrm{~s}$. & $87.643 \mathrm{~s}$ & $63.618 \mathrm{~s}$ & $171.457 \mathrm{~s}$. \\
\hline & $7.542 \mathrm{~s}$ & $29.856 \mathrm{~s}$ & $38.956 \mathrm{~s}$ & $76.354 \mathrm{~s}$ \\
\hline & $\begin{array}{l}\text { (6.624 s.) } \\
83919 \mathrm{~s}\end{array}$ & $\begin{array}{l}9.187 \mathrm{~s} \\
3.566 \mathrm{~s}\end{array}$ & $-400 s$ & $\begin{array}{l}15.811 \mathrm{~s} \\
87.885 \mathrm{~s}\end{array}$ \\
\hline & - & $1.356 \mathrm{~s}$ & $4.618 \mathrm{~s}$ & $5.974 \mathrm{~s}$ \\
\hline & $122.409 \mathrm{~s}$. & $6.818 \mathrm{~s}$. & $700 \mathrm{~s}$ & $129.927 \mathrm{~s}$. \\
\hline & $2.325 \mathrm{~s}$ & $425 \mathrm{~s}$ & $365 \mathrm{~s}$ & $3.115 \mathrm{~s}$ \\
\hline & $25.810 \mathrm{~s}$. & $9.152 \mathrm{~s}$. & - & 34.962 \\
\hline & $5.423 \mathrm{~s}$ & $1.533 \mathrm{~s}$. & $580 \mathrm{~s}$ & 6.003 \\
\hline & $3.470 \mathrm{~s}$. & $1.432 \mathrm{~s}$. & $4.872 \mathrm{~s}$ & 9.714 \\
\hline & 277.718 s. $^{\prime}$ & $221.745 \mathrm{~s}$ & \multicolumn{2}{|c|}{$\begin{array}{r}142.219 \text { s. } 641.682 \mathrm{~s} . \\
+62.850 \text { s. }+64.850 \text { s. }\end{array}$} \\
\hline & & & 205.069 & \\
\hline
\end{tabular}

' Cal recordar que en la comptabilitat del Batlle General referida a la batllia de la ciutat de València hi ha més ingressos que aquests però cal fer una tria per separar els que són ordinaris dels extraordinaris, els quals hem comptat en altra part, així com les repeticions d'ingressos perquè procedeixen de les batllies locals. 
Aquesta suma de 62.850 s. a les rendes de l'Antic Patrimoni i als totals de la monarquia correspon al valor de les rendes de les quatre viles -Vall d'Uixò, Eslida, Almonezir i Castro-, que apareixen amb el seu valor global i no arrendat per impostos, per la qual cosa no hem pogut destriar la seua composició.

QUADRE 31.

\section{VALOR DE LES RENDES PER POBLACIONS}

Ciutat de València .... $268.694 \mathrm{~s}$.

Xàtiva ........ 40.255 s. Comtat de Xèrica .... 42.026 s.

Moreria de Xàtiva .... 12.161 s. Paterna .......... 35.899 s.

Morella ......... 45.966 s. Benaguasil ........ 27.457 s.

Morvedre ........ 28.117 s. La Pobla Vallbona ... 7.393 s.

Alzira .......... 28.051 s. (les dues) ..... (34.850 s.)

Castelló ........ 17.750 s. Eslida .......... $23.500 \mathrm{~s}$.

Ontinyent . . ..... 8.393 s. Vall d'Uixò ....... 21.500 s.

Oriola . . . . . . . 8.216 s. Sogorb . . . . . . . . $18.293 \mathrm{s.}$

Borriana . . . . . . $6.968 \mathrm{~s}$. Vall d'Almonesir .... $14.550 \mathrm{~s}$.

Alpont ......... 5.645 s. Llíria .......... $11.151 \mathrm{~s}$.

Vila Real ........ 5.124 s. Castro-Fondeguilla ..... 3.300 s.

Cullera ............... $3.570 \mathrm{~s}$.

Penàguila . . . . . $3.290 \mathrm{~s}$.

Biar .......... $3.284 \mathrm{~s}$.

Castellfabib ...... 2.086 s.

Xixona ......... $1.720 \mathrm{~s}$.

Ademús . . . . . $1.309 \mathrm{~s}$.

Alacant $\ldots \ldots \ldots \ldots$ -

\section{RÉSUMÉ}

On n'a pas, jusqu'ici, dédié beaucoup de temps à l'étude du Patrimoine Royal Médiéval en Pays Valencien. Nous disposons de bien peu d'informations sur les villages que le formaient, sur le type de fiscalité royale qui s'y pratiquait, sur les 
biens possédés ou sur la valeur des impôts perçus ainsi que sur la gestion qu'y pratiquait l'administration royale.

Ce travail a été réalisé dans le but de colmater ce vide. Il analyse en détail les sources existantes traitant de cette fiscalité royale ordinaire au Pays Valencien au début du $\mathrm{XV}^{\mathrm{em}}$ siècle.

L'existence d'un manuscrit du Bailli Général du Règne, portant la date de 1414 a 1416, probablement lié à la proclamation du nouveau monarque Ferran I", a permis, en s'ajoutant à la documentation des maires locaux, de reconstruire les composants exacts de la fiscalité royale appliquée dans chacune des villes du pays valencien pendant ce règne, ainsi que sa valeur économique et l'identification assez importante du nombre et de la qualité des monopoles et droits régaliens que la couronne y conservait.

Nous avons aussi intégré l'étude d'une douzaine de villes et villages sarrasins qui formaient ce que l'on appelait l'Ancien Patrimoine, c'est à dire, la seigneurie particulière de la couronne pendant cette décennie et en tant que tel, source de revenus pour elle. Dans ce cas précis nous avons réalisé les tableaux avec le type de revenus et leur valeur.

Finalement on peut lire dans cet article quelques considérations générales sur les revenus de la monarchie, à cette époque, aux pays valenciens et quelques conclusions sur le peu de valeur réelle de cette fiscalité, comparée à la croisance de la fiscalité extraordinaire, tant à travers les demandes directes de la couronne, comme à travers les impôts commerciaux de la Généralité et les subsides des Cortes.

Le travail conclue avec une carte du Patrimoine Royal au début du $\mathrm{XV}^{\text {ème }}$ siècle, et des graphiques représentant les revenus, ville par ville, en pays valenciens.

\section{SUMMARY}

Till now, we have not dedicated much time to the study of Valencian Medieval Royal Patrimony. Very little information is in fact available on the villages that formed it, on the type of royal taxes applied, on the goods possessed or on the value of the taxes collected, as well as on the part taken by the royal administration.

This work has been realised with the purpose of filling this gap. It analyzes in details the existing sources about this ordinary royal tax system in Valencian counties at the beginning of the $\mathrm{XV}^{\text {th }}$ century.

A manuscript of the General Baillif of the reign -dated between 1414 and 1416 , and probably related to the proclamation of the new monarch Ferran I"allowed us, adding it to documents of the local mayor, to reconstruct the exact composition of the royal tax system applied in each of the cities of the Valencian patrimony realm during that reign. We also managed to determine its economic value as vell as the quite important identification of quantity and quality of monopolies and royal prerogatives that the crown reserved for herself.

We have also included the study of a dozen of Saracen towns and villages that formed the so-called Ancien Patrimony, which is the particular seigniory of the 
crown during that decade and is, thus, a source of receipts for her. In this very precise case, we have drawn the tables indicating the types of receipts and their value.

Finally, we can find in this article some general considerations on monarchy receipts, by that time, in Valencian counties, and a couple of conclusions on the really weak value or importance of this tax system, compared with the increase of the extraordinary parallel tax system, acting as much trough direct requests of the crown as trough commercial taxes of the Generalitat and the grants of the Spanish Parliament.

The work ends with a map of the Royal Patrimony at the beginning of the $\mathrm{XV}^{\text {th }}$ century and some graphs representing the receipts, separately for each town, in the Valencian counties. 